\title{
TRPV1 and TRPA1 in cutaneous neurogenic and chronic inflammation: pro-inflammatory response induced by their activation and their sensitization
}

\author{
Olivier Gouin ${ }^{1,2}$, Killian L'Herondelle ${ }^{1}$, Nicolas Lebonvallet ${ }^{1}$, Christelle Le Gall-lanotto $^{1}$, Mehdi Sakka ${ }^{1}$, \\ Virginie Buhé ${ }^{1}$, Emmanuelle Plée-Gautier ${ }^{1}$, Jean-Luc Carré ${ }^{1}$, Luc Lefeuvre ${ }^{2}$, Laurent Misery ${ }^{1 凶}$, \\ Raphaele Le Garrec ${ }^{1}$ \\ ${ }^{1}$ Laboratory on Interaction Neurons-Keratinocytes (LINK), University of Western Brittany, 29200 Brest, France \\ ${ }^{2}$ Uriage Dermatological Laboratories, 92400 Courbevoie, France \\ $\triangle$ Correspondence: laurent.misery@chu-brest.fr (L. Misery) \\ Received January 9, 2017 Accepted February 28, 2017
}

\begin{abstract}
Cutaneous neurogenic inflammation (CNI) is inflammation that is induced (or enhanced) in the skin by the release of neuropeptides from sensory nerve endings. Clinical manifestations are mainly sensory and vascular disorders such as pruritus and erythema. Transient receptor potential vanilloid 1 and ankyrin 1 (TRPV1 and TRPA1, respectively) are non-selective cation channels known to specifically participate in pain and $\mathrm{CNI}$. Both TRPV1 and TRPA1 are co-expressed in a large subset of sensory nerves, where they integrate numerous noxious stimuli. It is now clear that the expression of both channels also extends far beyond the sensory nerves in the skin, occuring also in keratinocytes, mast cells, dendritic cells, and endothelial cells. In these non-neuronal cells, TRPV1 and TRPA1 also act as nociceptive sensors and potentiate the inflammatory process. This review discusses the role of TRPV1 and TRPA1 in the modulation of inflammatory genes that leads to or maintains CNI in sensory neurons and non-neuronal skin cells. In addition, this review provides a summary of current research on the intracellular sensitization pathways of both TRP channels by other endogenous inflammatory mediators that promote the self-maintenance of $\mathrm{CNI}$.
\end{abstract}

KEYWORDS sensory nerve, neurogenic skin inflammation, inflammatory gene regulation, pruritus

\section{INTRODUCTION}

CNI definition, induction, and self-maintenance

Cutaneous neurogenic inflammation $(\mathrm{CNI})$ is the inflammation induced (or enhanced) by an excessive release of neuropeptides such as calcitonin gene-related peptide (CGRP) and tachykinins (mainly substance P, SP) in the skin from locally or antidromically activated sensory nerve endings (Herbert and Holzer, 2002; Roosterman et al., 2006; Gouin et al., 2015).

CNI can be induced through the direct activation of receptors on sensory nerve endings by mechanical skin injuries and other exogenous stimuli, such as exposure of the skin to injurious heat or cold, ultraviolet (physical factors), chemical irritants or allergens. Endogenous stimuli, including osmotic or $\mathrm{pH}$ changes in the skin, can also initiate CNI (Herbert and Holzer, 2002; Roosterman et al., 2006). The released neuropeptides act on skin cells that express cognate neuropeptide receptors, including microvascular cells and resident mast cells, leading to degranulation, vasodilation, and extravasation of plasma proteins and leukocytes. Some clinical manifestations of acute $\mathrm{CNI}$ are localized pruritus, redness, heat, and edema (Herbert and Holzer 2002; Roosterman et al., 2006; Teresiak-Mikołajczak et al., 2013).

Moreover, neuropeptides and mast cell-released mediators can act on other neighboring target cells, including keratinocytes, dendritic cells, neutrophils and fibroblasts, leading to the disruption of skin homeostasis, with abnormal skin growth, differentiation, and/or immunomodulation (Shim 
et al., 2007; Trevisani et al., 2007; Wilson et al., 2013b; Patricio et al., 2015).

Furthermore, a variety of neurotrophic (e.g. nerve growth factor, NGF) or inflammatory mediators (e.g. proteases, histamine, cytokines, prostanoids) or endocannabinoids (e.g. anandamide) released by skin cells/nerve fibers or chemoattracted cells are able to further activate or sensitize these sensory receptors (Briot et al., 2009; Vellani et al., 2010; Roosterman et al., 2006; Riol-Blanco et al., 2014; Wilson et al., 2013b; Wei et al., 2012). Such positive feedback loops contribute to the enhancement of the inflammatory process and thus to self-maintained CNI (Gouin et al., 2015).

Therefore, CNI appears to be a multi-cellular network with multiple, multi-directional interactions leading to a vicious circle of processes that results in chronic inflammation (Gouin et al., 2015). Indeed, CNI is frequently involved in chronic inflammatory skin disorders, including psoriasis, atopic dermatitis (AD) (Kubanov et al., 2015; Smolyannikova et al., 2015), sensitive skin (Costa et al., 2014), rosacea (Kürkçüoğlu and Alaybeyi 1991; Salem et al., 2013), and hypertrophic scars (Akaishi et al., 2008; Kwak et al., 2014).

\section{Role of PARs and TRPs}

Although the exocytosis of neuropeptides from large densecore vesicles differs from that of classical neurotransmitters from small clear vesicles, it is also triggered by a rise in the cytosolic $\mathrm{Ca}^{2+}$ concentration (Huang and Neher 1996; Zupanc 1996; Jans et al., 2004). Two primary pathways lead to increased $\mathrm{Ca}^{2+}$ concentration in the cytosol, the $\mathrm{Ca}^{2+}$ influx associated with the opening of plasmalemmal $\mathrm{Ca}^{2+}$ channels and the $\mathrm{Ca}^{2+}$ released from intracellular stores (the endoplasmic reticulum and mitochondria). In addition to voltage-gated $\mathrm{Ca}^{2+}$ channels, cutaneous sensory nerves express cationic channels and $G$ protein-coupled receptors (GPCRs), the activation of which can lead directly or indirectly to an increase in cytosolic $\mathrm{Ca}^{2+}$. In addition to the induction of neuropeptide release, an increase in cytosolic $\mathrm{Ca}^{2+}$ can also drive the regulation of the expression of several inflammatory genes, such as those encoding neuropeptides, cytokines, growth factors, prostaglandins (PG), and matrix metalloproteinases (MMPs), which have a possible role in chronic cutaneous inflammation.

Interestingly, cationic channels expressed by cutaneous nerve endings include some transient receptor potential (TRP) channels known to be involved in neuropeptide exocytosis and skin disorders that have neurogenic mechanisms. In this review we focus on two of these channels including TRPV1 and TRPA1 (TRP subfamily vanilloid 1 and TRP subfamily ankyrin 1, respectively) (Xie 2009; Wei et al., 2010; Boillat et al., 2014; Horváth et al., 2015). Other TRP channels have also been found to be involved in $\mathrm{CNI}$ and pruritus such as TRPV3 (Lin et al., 2012) and TRPV4 (Zhao et al., 2014; Rajasekhar et al., 2015; Akiyama et al., 2016; Kim et al., 2016). In addition, the sensory nerves in the skin also express GPCRs, of which the protease-activated receptor (PAR) family in particular is known to be involved in CNI, especially PAR-2 and PAR-4 (Cocks and Moffatt 2000). Thus, TRPV1, TRPA1, PAR-2, and PAR-4 are associated not only with a rise in the intracellular $\mathrm{Ca}^{2+}$ concentration $\left(\mathrm{iCa}^{2+}\right)$ with the subsequent exocytosis of neuropeptides but also with pro-inflammatory gene expression (Fig. 1). Moreover, following the activation of one of these receptors, intracellular pathways can lead to the sensitization of one of these channels.

In addition to their expression by sensory nerves, TRPV1, TRPA1, PAR-2, and PAR-4 are found in resident skin cells or cells recruited during CNI. Thus, they could contribute to the intense and narrow communication within the skin between sensory nerve endings, skin, and immune cells.

This review discusses the role of TRPV1 and TRPA1 activation or signaling pathways associated with their sensitization in the self-maintenance of $\mathrm{CNI}$ through the induction of a pro-inflammatory response in the skin.

\section{TRPV1}

A cationic channel with multiple direct roles in CNI induction and self-maintenance

TRPV1 is a nociceptive cationic (mainly $\mathrm{Ca}^{2+}$ ) channel responsive to high temperature $\left(>43^{\circ} \mathrm{C}\right)$ (Boillat et al., 2014). In addition to excessive heat, various exogenous and endogenous triggering factors can directly activate or sensitize TRPV1 (Table 1). TRPV1 was initially described in cutaneous $\mathrm{C}$ - and $\mathrm{A} \delta$-type sensory nerve endings, where it plays a critical role. It can be activated by the natural agonist capsaicin (Jancsó et al., 1967; Caterina et al., 1997). High temperature and capsaicin have been demonstrated to activate sensory nerves and induce neurogenic inflammation (Jancsó et al., 1967; Caterina et al., 1997). Indeed, TRPV1 activation by these direct activators allows the entry of $\mathrm{Ca}^{2+}$, leading to the release of neuropeptides, including SP (Andreev et al., 2012) and CGRP (Boillat et al., 2014), that control edema and can induce (or enhance) neurogenic inflammation (Szallasi and Blumberg 1989; Zygmunt et al., 1999; Steinhoff et al., 2003; Roosterman et al., 2006; Vincent et al., 2013).

Furthermore, endogenous mediators produced or released during CNI (eicosanoids, acidosis, ATP, histamine, bradykinin, NGF) that further sensitize or activate TRPV1 on skin nerve terminals contribute to the self-maintenance of $\mathrm{CNI}$ (Roosterman et al., 2006). Moreover, TRPV1 was found to be expressed in skin cells (keratinocytes, dermal mast cells, dendritic cells, sebocytes, dermal blood vessels, hair follicles, and sweat glands), where it acts as a pain and chemical sensor (Ständer et al., 2004).

\section{TRPV1 sensitization/desensitization by endogenous modulators following intracellular pathway activation}

\section{Intracellular pathways of TRPV1 sensitization}

The TRPV1 sensitization process is an intracellular mechanism that facilitates the gating of the channel or strengthens 


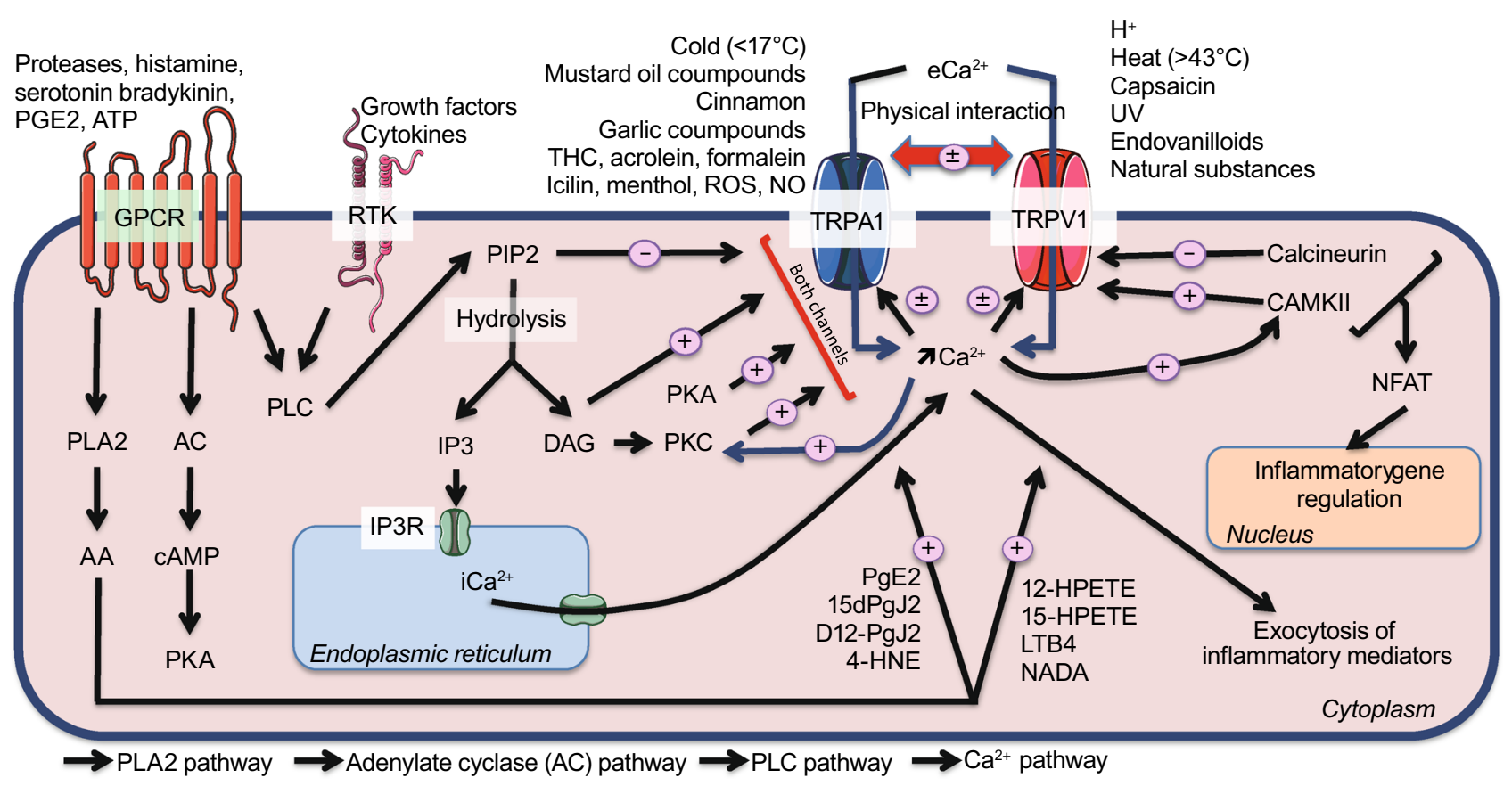

Figure 1. Common intracellular GPCR, RTK and $\mathrm{Ca}^{2+}$ pathways regulate via the activation and sensitization of TRPV1 and TRPA1. The G protein-coupled receptor (GPCR) and receptor tyrosine kinase (RTK) activation stimulate phospholipase C (PLC), which leads to phosphatidylinositol 4,5-bisphosphate (PIP2) hydrolysis and the consequent release of the transient receptor potential (TRP) channels from its inhibitory control, triggering the formation of 1,4,5-trisphosphate (IP3) and diaglycerol (DAG) as well as the influx of $\mathrm{Ca}^{2+}$ via TRP vanilloid 1 and ankyrin 1 (TRPV1 and TRPA1). Then, DAG can directly activate both TRP channels, and protein kinase $C$ (PKC) activation by DAG enhances TRP activity, sensitizing both channels. IP3 formation promotes $\mathrm{Ca}^{2+}$ release from the endoplasmic reticulum and increases the $\mathrm{iCa}^{2+}$ concentration. GPCRs can also activate the phospholipase A2 (PLA2) and adenylate cyclase pathways, which lead to protein kinase $A(P K A)$ stimulation and the formation of arachidonic acid (AA) metabolites and products. PKA acts directly sensitize the TRP channels, while AA metabolites and products directly activate the TRP channels. Both TRPV1 and TRPV1 can directly or indirectly regulate the activity of the other by direct interaction or via the $\mathrm{iCa}^{2+} \mathrm{concentration}$ resulting in a cross-sensitization/desensitization process. The elevation of $\mathrm{iCa}^{2+}$ triggers the exocytosis of inflammatory mediators and stimulates both $\mathrm{Ca}^{2+} /$ calmodulin-dependent kinase II (CAMKII) and calcineurin, which sensitize and desensitize TRPV1, respectively. Both kinases are also involved in the regulation of inflammatory genes via nuclear factor of activated T-cell (NFAT) translocation to the nucleus.

the currents evoked during the subsequent activation of TRPV1. The structure of TRPV1 was obtained by high-resolution cryo-electron microscopy (cryo-EM) and revealed multiple intracellular regulatory domains (Liao et al., 2013). TRPV1 is a polymodal receptor whose sensitization and endogenous regulatory pathways act via phosphorylation sites for kinases such as protein kinases $C$ and A (PKC and PKA) and $\mathrm{Ca}^{2+} /$ calmodulin dependent kinase II (CAMKII). PKC phosphorylates and sensitizes TRPV1 at the S502 and S800 phosphorylation sites (Numazaki et al., 2002; Bhave et al., 2003). The PKA phosphorylation sites S116, T370, S502, and T144 appear to sensitize TRPV1 and prevent its desensitization upon the repeated application of capsaicin (Bhave et al., 2002; Mohapatra and Nau 2003; Mohapatra and Nau 2005; Amadesi et al., 2006). Several studies have identified two specific phosphorylation sites for CAMKII on
TRPV1 (S502 and T704) that modulate vanilloid binding. Thus, in human embryonic kidney-derived (HEK293) cells expressing $\Delta 774-838$-deleted CaMKII phosphorylation sites (Woo et al., 2008) or S502A/T704l mutants of TRPV1, capsaicin does not evoke a current, which suggests that phosphorylation by CaMKII is required to control the responsiveness of TRPV1 to the ligand (Jung et al., 2004).

Phospholipase C (PLC) activity goes through the decrease of phosphatidylinositol 4,5-bisphosphate (PIP2) level and through the production of diacylglycerol (DAG), both of which are involved in TRPV1 sensitization. Indeed, the correlation between PIP2 and the intracellular sensitization of TRPV1 has been established; both bradykinin and NGF (known to stimulate PLC pathways after binding to their cognate receptors) potentiated TRPV1 activity in a heterologous expression system and in dorsal root ganglion (DRG) 
Table 1. Endogenous and exogenous agonists involved in TRPV1 activation, sensitization, and inhibition

\begin{tabular}{|c|c|c|}
\hline Factors & Pathways of activation & References \\
\hline \multicolumn{3}{|c|}{ Exogenous activators of TRPV $1^{\mathrm{a}}$ : } \\
\hline $\begin{array}{l}\text { High temperature }\left(>43^{\circ} \mathrm{C}\right) \\
\text { Protons }(\mathrm{pH}<5.9)\end{array}$ & \multirow{3}{*}{$\begin{array}{l}\text { Direct activation: } \\
\text {-Inward current } \\
-\mathrm{iCa}^{2+} \text { elevation } \\
\text {-Neuropeptide release } \\
\text {-Inflammatory mediator release }\end{array}$} & $\begin{array}{l}\text { (Boillat et al., 2014) } \\
\text { (Caterina et al., 1997) } \\
\text { (Tominaga et al., 1998) }\end{array}$ \\
\hline Ultraviolet & & (Lee et al., 2009, 2011) \\
\hline $\begin{array}{l}\text { Vanilloids: } \\
\text {-Olvanil } \\
\text {-Resiniferatoxin } \\
\text { Natural substances: } \\
\text {-Camphor } \\
\text {-Piperin } \\
\text {-Capsaicin }\end{array}$ & & $\begin{array}{l}\text { (Caterina et al., 1997) } \\
\text { (Szallasi and Blumberg 1989) }\end{array}$ \\
\hline \multicolumn{3}{|c|}{ Endogenous activators of TRPV1: } \\
\hline Anandamide & \multirow{2}{*}{$\begin{array}{l}\text { Direct activation: } \\
\text {-Inward current } \\
-\mathrm{iCa}^{2+} \text { elevation } \\
\text {-Neuropeptide release } \\
\text {-Inflammatory mediator release }\end{array}$} & $\begin{array}{l}\text { (Smart et al., 2000) } \\
\text { (Zygmunt et al., 1999) }\end{array}$ \\
\hline $\begin{array}{l}\text { AA } A^{b} \text { metabolites: } \\
\text {-NADA } \\
\text {-ODA } \\
\text { Lipooxygenase products: }^{\mathrm{c}} \\
\text {-HPETE } \\
\text {-15-HPETE } \\
\text {-LTB4 }^{\mathrm{f}}\end{array}$ & & $\begin{array}{l}\text { (Huang et al., 2002) } \\
\text { (Hwang et al., 2000) }\end{array}$ \\
\hline $\begin{array}{l}\text { DAG }^{\mathrm{h}} \\
\text { CAMKII }^{\mathrm{i}}\end{array}$ & $\begin{array}{l}\text { Phosphorylation of TRPV1 } \\
\text { (S502 and T704) }\end{array}$ & $\begin{array}{l}\text { (Jung et al., 2004) } \\
\text { (Woo et al., 2008) }\end{array}$ \\
\hline $\mathrm{PIP}^{\mathrm{j}}$ & Binding the extracellular leaflet (site: $777-820$ ) & $\begin{array}{l}\text { (Senning et al., 2014) } \\
\text { (Ufret-Vincenty et al., 2015) }\end{array}$ \\
\hline \multicolumn{3}{|c|}{ Indirect activators/sensitizers of TRPV1: } \\
\hline $\begin{array}{l}\text { Bradykinin } \\
\text { Growth factors (e.g., NGF }{ }^{k} \text { ) } \\
\text { PgE2 }\end{array}$ & $\begin{array}{l}\mathrm{BK}^{2} \mathrm{R}^{\mathrm{p}}\left(\mathrm{GPCR}^{\mathrm{q}}\right) \\
\mathrm{RTK}^{\mathrm{r}} \\
\mathrm{EPR}^{\mathrm{s}}(\mathrm{GPCR})\end{array}$ & $\begin{array}{l}\text { (Chuang et al., 2001) } \\
\text { (Vellani et al., 2001) } \\
\text { (Zhang et al., 2008) }\end{array}$ \\
\hline Proteases & PAR-2 and PAR- $4^{t}$ (GPCR) & $\begin{array}{l}\text { (Amadesi et al., 2004, 2006) } \\
\text { (Vellani et al., 2010) }\end{array}$ \\
\hline Serotonin & 5-HTR ${ }^{\mathrm{u}}(\mathrm{GPCR})$ & (Sugiura et al., 2002) \\
\hline Histamine & $\mathrm{H} 1 \mathrm{R}$ and $\mathrm{H}_{4} \mathrm{R}^{\mathrm{v}}$ (GPCR) & $\begin{array}{l}\text { (Jian et al., 2016) } \\
\text { (Shim et al., 2007) }\end{array}$ \\
\hline ATP $^{m}$ & P2Y1R ${ }^{w}$ (GPCR) & $\begin{array}{l}\text { (Numazaki et al., 2002) } \\
\text { (Tominaga et al., 2001) }\end{array}$ \\
\hline TRPA $^{\mathrm{n}}$ & $\begin{array}{l}\text { Physical interaction or } \\
\mathrm{Ca}^{2+} \text { second messenger }\end{array}$ & $\begin{array}{l}\text { (Anand et al., 2008) } \\
\text { (Alpizar et al., 2013) } \\
\text { (Spahn et al., 2014) }\end{array}$ \\
\hline DAG & Indirectly by $\mathrm{PKC}^{\mathrm{x}}$ activation & $\begin{array}{l}\text { (Burgess et al., 1989) } \\
\text { (Chuang et al., 2001) } \\
\text { (Cesare et al., 1999) }\end{array}$ \\
\hline \multicolumn{3}{|c|}{ Inhibitors/desensitizers of TRPV1: } \\
\hline Calcineurin $^{\circ}$ & $\mathrm{iCa}^{2+}$-dependent dephosphorylation of TRPV1 & $\begin{array}{l}\text { (Docherty et al., 1996) } \\
\text { (Jeske et al., 2006) } \\
\text { (Patwardhan et al., 2006) }\end{array}$ \\
\hline PIP2 & Binding the intracellular leaflet (site: $777-820$ ) & $\begin{array}{l}\text { (Senning et al., 2014) } \\
\text { (Ufret-Vincenty et al., 2015) } \\
\text { (Woo et al., 2008) } \\
\text { (Chuang et al., 2001) }\end{array}$ \\
\hline
\end{tabular}


Table 1. continued

\begin{tabular}{lll}
\hline Factors & Pathways of activation & References \\
\hline TRPA1 & $\begin{array}{l}\text { Physical interaction or } \\
\text { iCa }\end{array}$ & (Akopian et al., 2007) \\
& (Patil et al., 2010)
\end{tabular}

neurons (Chuang et al., 2001). The role of PIP2 as a TRPV1 inhibitor or "desensitizer" after its depletion by sequestration or PLC hydrolysis has been subsequently shown to be essential for TRPV1 sensitization (Prescott and Julius 2003). In addition, the lack of a PIP2 binding site (786-828) increased the strong inward current evoked by a DAG analog and capsaicin in a $\triangle 774-838$ deletion mutant of TRPV1 (Woo et al., 2008). However, PIP2 could activate TRPV1 by binding the extracellular leaflet (777-820), while it has an inhibitor effect by binding the intracellular leaflet (682-725) (Senning et al., 2014; Ufret-Vincenty et al., 2015). Interestingly, in addition to its ability to directly activate TRPV1 via a PKC-independent pathway by binding to the capsaicin binding site at Y511; (Woo et al., 2008)), DAG could also contribute to the indirect sensitization of TRPV1 via PKC phosphorylation at the S502 and S801 sites (Burgess et al., 1989; Cesare et al., 1999; Chuang et al., 2001) (Numazaki et al., 2002; Bhave et al., 2003).

Finally, it might be noticed that the prolonged or repeated activation of TRPV1 induces a desensitization or inhibition process. It has been observed that the repeated activation of TRPV1 by chemical stimuli results in its desensitization by a $\mathrm{Ca}^{2+}$-dependent process (Chuang et al., 2001; Bhave et al., 2002; Dai et al., 2004). Protein phosphatase 2B (calcineurin) acts as a desensitizer of TRPV1, as indicated by the inhibition of calcineurin by cyclosporine or CsA-CyP, which have been shown to inhibit the desensitization of TRPV1 induced by capsaicin (Docherty et al., 1996; Mohapatra and Nau 2005). The cannabinoid WIN 55,212-2 seems to play an antiinflammatory and analgesic role via the inhibition of TRPV1 by dephosphorylating the T144 and T370 sites in a $\mathrm{Ca}^{2+}$ calcineurin-dependent manner, reducing the release of CGRP (Patwardhan et al., 2006; Jeske et al., 2006). These data show the potential effects of calcineurin inhibitors on TRPV1 desensitization and suggest cannabinoids as new therapeutic drugs for $\mathrm{CNI}$, hyperalgesia, itching, and pain.

\section{Inflammatory mediators that use TRPV1 intracellular sensitization pathways}

Following tissue damage, endogenously released inflammatory mediators (ATP, bradykinin, serotonin PGs, NGF, chemokines, histamine or proteases) can regulate TRPV1 activity via intracellular pathways associated with their specific GPCR. For example, in transfected HEK293 cells and DRG neurons, ATP increased capsaicin-induced TRPV1 activation via the purinergic receptor P2Y1, which potentiated TRPV1 activity in a PKC-dependent pathway (Tominaga et al., 2001; Numazaki et al., 2002). In the same way, in a $\mathrm{Ca}^{2+}$ - and PLC/PKC-dependent manner, bradykinin, serotonin (G protein-coupled 5-HT receptor), PgE2 (G protein-coupled EP receptors), and NGF enhanced capsaicin-, heat-, proton-, and anandamine-evoked currents (Vellani et al., 2001; Sugiura et al., 2002; Zhang et al., 2008; Wilson et al., 2011). Similarly, the chemokine CCL3 was found to sensitize TRPV1 by increasing the heat-, anandamide-, and capsaicin-evoked $\mathrm{Ca}^{2+}$ influx through a PLCand PKC-pathway in HEK293 cells and DRG neurons (Zhang et al., 2005).

Finally, histamine enhanced the capsaicin-mediated inward current, increased the $\mathrm{Ca}^{2+}$ level and then induced itching via sensory neurons, and this effect was abolished by TRPV1 antagonists and in TRPV1-deficient mice (Shim et al., 2007). These mechanisms appeared to involve phospholipase A2 (PLA2)-, lipoxygenase (NDGA)- and PLCdependent pathways, with the subsequent sensitization and activation of TRPV1 (Jian et al., 2016). These studies suggest that TRPV1 is involved in histamine-dependent itching with arachidonic acid metabolites, primarily 12-hydroxyeicosatetraenoic (12-HETE), acting as a central participant (Shim et al., 2007).

Because of their ability to cleave and thus activate specific PARs, endogenous proteases play a specific role in CNI. Both PAR-2 and PAR-4 are known to induce $\mathrm{CNI}$ and therefore to be involved in several skin disorders, such as pruritus and AD (Asfaha et al., 2007; Briot et al., 2009; Vellani et al., 2010; Fu et al., 2014). In addition to their ability to induce CNI via the release of SP and CGRP, it has clearly been established that PAR-2 and PAR-4 activation could lead to TRPV1 sensitization. Patch clamp and $\mathrm{Ca}^{2+}$ imaging assays in HEK293 cells that co-express TRPV1 and PAR-2 and DRG neurons revealed that PAR-2 activation potentiates TRPV1 via phosphorylation by PKC- and PKA-dependent pathways (Amadesi et al., 2004; Dai et al., 2004; 
Amadesi et al., 2006). As a consequence, TRPV1 sensitization by a PAR-2 agonist reduced the temperature threshold for TRPV1 from $42^{\circ} \mathrm{C}$ to $33^{\circ} \mathrm{C}$, leading to thermal hyperalgesia, pain, and inflammation (Dai et al., 2004; Amadesi et al., 2006; Amadesi et al., 2006). In addition, PAR-2 agonists potentiated the capsaicin-evoked CGRP and SP release from sensory neurons and thus enhanced CNI and hyperalgesia (Hoogerwerf et al., 2001; Amadesi et al., 2004). On the other hand, the involvement of PAR-4 activation in TRPV1 sensitization has been poorly studied. One study demonstrated that PAR-4 activation potentiated TRPV1 activation via a PKC-dependent pathway (Vellani et al., 2010; Patricio et al., 2015).

Altogether, mediators released in inflamed skin could contribute to peripheral sensitization, especially via TRPV1 sensitization, thus facilitating pain and itching. TRPV1 activation and/or sensitization can enhance peripheral inflammatory responses via the expression and release of other inflammatory mediators.

\section{Pro-inflammatory responses induced by TRPV1 activation}

In addition to the clearly established role of TRPV1 in the release of neuropeptides from sensory neurons, its ability to increase the expression of inflammatory genes potentially involved in $\mathrm{CNI}$, such as those for inflammatory cytokines, PGs and MMPs, has been shown in a few studies. The activation of TRPV1 by protons led to up-regulation of the expression of CGRP via CaMKII and CREB activation in DRG neurons. In addition, the proton-mediated induction of inflammatory pain and CGRP expression in DRG neurons was inhibited in TRPV1-deficient mice (Nakanishi et al., 2010). Another study showed that TRPV1 activation by capsaicin induced the PKC pathway-mediated up-regulation of TRPV1 and CGRP expression in acute CNI and increased PAR-4 mRNA and protein levels via a cAMP/PKA signaling pathway in cultured primary DRG neurons (Chen et al., 2013). Thus, it appears that a narrow interactive relationship between PAR-4 and TRPV1 exists in the development of $\mathrm{NCl}$ or in nociception from primary afferent neurons (Russell et al., 2010; Vellani et al., 2010; Chen et al., 2013; Gouin et al., 2015).

In addition to neuropeptide release, TRPV1-mediated $\mathrm{Ca}^{2+}$ influx in the skin could induce the expression or the release of other pro-inflammatory mediators and affect skin immune cells, contributing to the self-maintenance of $\mathrm{CNI}$ and/or cutaneous chronic inflammation.

In addition to TRPV1 activation in the sensory nerves, TRPV1 activation in human epidermal keratinocytes by capsaicin, acidification or ultraviolet (UV) radiation evoked an increase in the $\mathrm{iCa}^{2+}$ concentration (Inoue et al., 2002; Lee et al., 2009). In fact, several studies have shown that the exposure of keratinocytes to capsaicin or UV radiation leads to TRPV1-mediated $\mathrm{Ca}^{2+}$ influx, followed by the increased expression of cyclo-oxygenase (COX)-2, inflammatory mediators (e.g., interleukin (IL)-1 $\beta$, IL-2, IL-4, and IL-8, tumor necrosis factor (TNF)- $\alpha$, PGE2, and LTB4, as well as several MMPs, including MMP-13, 9, 3, and 2) (Inoue et al., 2002; Southall et al., 2003; Lee et al.. 2009; Jain et al., 2011; Lee et al., 2011). In an epithelial airway cell line, TRPV1 activation by capsaicin evoked the expression and release of thymic stromal lymphopoietin (TSLP) via $\mathrm{Ca}^{2+}$ elevation and calcineurin-mediated NFAT activity (Jia et al., 2014). For keratinocytes, no relation between TSLP secretion and TRPV1-mediated $\mathrm{Ca}^{2+}$ influx has been demonstrated, and this association needs to be investigated. Altogether, these mediators released by keratinocytes cause erythema, pain, and a UV-induced skin response and thickening (Lee et al., 2009; Jain et al., 2011; Lee et al., 2011). Moreover, they are known to sensitize TRPV1 in nociceptive neurons, with subsequent CGRP release and CNI (Hwang et al., 2000; Oprée and Kress 2000; Binshtok et al., 2008).

Immune cells present in the skin, such as mononuclear cells, dendritic cells (DCs) and mast cells, also express TRPV1, and TRPV1 activation directly affects the function of these cells (Saunders et al., 2009; Basu and Srivastava 2005; Ständer et al., 2004). Indeed, activation of TRPV1 in mononuclear cells induced cell death, and this response was reversed by a TRPV1 antagonist (Saunders et al., 2009). Capsaicin promotes DC maturation, which is abrogated in $\mathrm{TRPV}^{-1-} \mathrm{DC}$ cells. In an in vivo mouse model, injected capsaicin mediated the maturation and migration of skin DCs to the draining lymph nodes in TRPV $1^{+/+}$but not in TRPV1 $1^{-1-}$ mice, confirming an important role for this channel in the innate immunity process (Basu and Srivastava 2005). Nevertheless, the potential inflammatory role of TRPV1 in DCs remains controversial, as evidenced by another study that did not find TRPV1 expression in DCs or the induction of calcium elevation by capsaicin. However, the neuropeptide $\mathrm{SP}$ activated DCs by eliciting robust $\mathrm{Ca}^{2+}$ elevation, suggesting that DC maturation and migration are dependent on CNI. Taken together, the potential inflammatory role of TRPV1 in DCs remains unclear and needs to be investigated. The involvement of mast cell degranulation during $\mathrm{CNI}$ in response to capsaicin is a related process that occurs indirectly via the release of peptide transmitters from sensory neurons (Bunker et al., 1991; Frydas et al., 2013). Nonetheless, TRPV1 activation by capsaicin has evoked $\mathrm{Ca}^{2+}$ elevation in numerous mast cell lines. Capsaicin-elicited $\mathrm{Ca}^{2+}$ did not induce mast cell degranulation but triggered the release of IL-4 (B'iró et al., 1998), which is known to be involved in $A D$ associated with the recruitment of neutrophils, macrophages, $\mathrm{CD}^{+}$lymphocytes, and epidermal dendritic T lymphocytes (Zhao et al., 2016).

TRPV1 is also expressed in endothelial cells and smooth muscle cells, and its activation induces vasorelaxation by releasing nitric oxide (NO) by a $\mathrm{Ca}^{2+}$ influx-dependent mechanism (Yang et al., 2010; Ching et al., 2011; Himi et al., 2012). Endothelium-dependent vasodilatation is in turn dependent on endothelial nitric oxide synthase (eNOS) and 
TRPV1, as evidenced by the inhibition of capsaicin-evoked dilatation by an eNOS inhibitor (L-NAME) and a TRPV1 antagonist (capsazepine). These results confirmed that endothelial TRPV1 can induce vasodilatation via NO production (Kark et al., 2008; Yang et al., 2010). In addition to NO production, thermal endothelial-TRPV1 activation stimulated the endothelial cell-derived release of CGRP from endothelial cell lines, which contributed to the attenuation of endothelial cell damage (Ye et al., 2007; Luo et al., 2008). The CGRP receptor expressed on endothelial cells has been shown to have anti-inflammatory effects by inhibiting the production of the chemokines CXCL1, CCL2, and IL-8 (Huang et al., 2011). Taken together, these results indicate that endothelial TRPV1 acts as an anti-inflammatory factor both directly by inducing vasodilation via NO production and indirectly by inhibiting leukocyte recruitment via CGRP production.

In summary, TRPV1 activation mediates a narrow communication between sensory nerve endings, skin non-immune and immune cells, increasing release of inflammatory mediators (mainly cytokines and neuropeptides). These mediators act directly via specific receptors on neighboring cells, inducing the intracellular sensitization of TRPV1 and its activation. Hence, TRPV1 should be considered a central modulator of the self-maintenance of $\mathrm{CNI}$.

\section{TRPA1}

Another cationic channel with multiple direct roles in neurogenic inflammatory dermatitis and pruritus

TRPA1 is also a nociceptive cationic (mainly $\mathrm{Ca}^{2+}$ ) thermoresponsive channel that, in contrast to TRPV1, is implicated in cold thermal sensation (i.e., temperatures below $17^{\circ} \mathrm{C}$ ). Besides cold stimuli, a variety of exogenous and endogenous activators or sensitizers of TRPA1 have been identified (Table 2).

The presumption that TRPA1 is involved in CNI is growing. Indeed, TRPA1 has been found to be co-expressed with TRPV1 and neuropeptides (SP and CGRP) in a subset of nociceptive sensory neurons (Vellani et al., 2010; Story et al., 2003). Low temperature has been demonstrated to activate sensory nerves and induce neurogenic inflammation (Story et al., 2003; Obata et al., 2005). Indeed, TRPA1 activation stimulated (or increased) neuropeptide (SP and CGRP) release from sensory neurons in a $\mathrm{Ca}^{2+}$-dependent manner, with subsequent signs of $\mathrm{CNI}$, such as edema and leukocyte infiltration (Story et al., 2003; Meseguer et al., 2014; Trevisani et al., 2007; Thorne et al., 1991; Silva et al., 2011). In addition, a specific TRPA1 antagonist attenuated the capsaicin (a TRPV1 agonist)-evoked increase of cutaneous blood flow adjacent to an injury site in the plantar skin of rats, strongly suggesting that both TRP channels could cooperate in CNI induction (Wei et al., 2010).

TRPA1 is required for $A D$ and histamine-independent chronic itching. Indeed, in acute oxazolone-induced dermatitis in mouse ears, TRPA1-deficient mice or WT mice treated with the TRPA1 antagonist HC-030031 showed diminished skin inflammation, which was associated with a decrease in ear epidermal thickness, eosin-positive cells, and $\mathrm{CD}^{+}$and $\mathrm{CD}^{+} \mathrm{T}$ cells in the ear tissue. TRPA1-deficient mice also diminished SP- and oxazolone-evoked scratching behavior and $A D$ responses, as revealed by a decrease of dermatitis score, including erythema, scaring, excoriation, and swelling (Liu et al., 2013). Histamine-independent pruritus evoked by the TRPA1 agonists chloroquine, BAM8-22 or AEW was abrogated in neurons from TRPA1deficient mice, impairing the scratching behavior response and increasing epidermal thickness (Wilson et al., 2011; Wilson et al., 2013a). In addition, the inflammatory cytokine TSLP is highly expressed in skin epithelial cells from AD patients and induces (or enhances) skin inflammation via $\mathrm{T}$ cells, DCs, and mast cell activation (Ziegler et al., 2013; Moniaga et al., 2013). Within the skin, TSLP also activates sensory neurons via TSLPR, and, subsequently, TRPA1 stimulation via a PLC-mediated pathway, thereby evoking robust itching in mice (Wilson et al., 2013b). To date, there is no evidence that TSLP and TRPA1 can induce CNI by releasing neuropeptides.

Similar to TRPV1, TRPA1 is also under the control of an intracellular sensitization process involving several inflammatory mediators, such as growth factors, bradykinins, proteases, and cytokines. By its localization in neuronal and non-neuronal skin cells, TRPA1 potentiates neurogenic skin inflammation by enhancing cellular responses (Inoue et al., 2002; Bautista et al., 2013).

\section{TRPA1 sensitization/desensitization by endogenous} modulators following intracellular pathway activation

In a manner similar to that of TRPV1, TRPA1 activity is controlled by desensitization and sensitization processes. The repeated activation of TRPA 1 by chemical stimuli results in the $\mathrm{Ca}^{2+}$ - and current-dependent desensitization of TRPA1 (Story et al., 2003; Malin et al., 2011; Wilson and Bautista 2014). TRPA1 is a polymodal receptor with multiple intracellular ligand binding and phosphorylation sites that are involved in the activation and sensitization of this channel, respectively. Unlike most TRP channels, TRPA1 covalently interacts with many of its agonists through its $\mathrm{N}$-terminal region, which contains cysteine and lysine residues involved in its direct activation (Hinman et al., 2006; Macpherson et al., 2007). Direct mechanisms of TRPA1 activation have been described, although the precise mechanisms of sensitization/desensitization by which the inflammatory mediators potentiate the channel activity remain poorly understood. Recent data, using cryo-EM, provided for the first time the structure of TRPA1 and shown several similarities with TRPV1 (Paulsen et al., 2015). It is appeared that the NH2-terminal of TRPA1 has approximately 15 ankyrin repeats with several cysteine and lysine residues crucial for activation by reactive agonists (Hinman et al., 2006; 
Table 2. Endogenous and exogenous agonists involved in TRPA1 activation, sensitization, and inhibition

\begin{tabular}{|c|c|c|}
\hline Factors & Pathways of activation & References \\
\hline \multicolumn{3}{|l|}{ Exogenous activators of TRPA $1^{a}$ : } \\
\hline Cold temperature $\left(<17^{\circ} \mathrm{C}\right)$ & Direct activation: & (Bíró and Kovács 2009) \\
\hline $\begin{array}{l}\text { Mustard oil compounds: } \\
\text {-AITC } \\
\text {-Benzyl isothiocyanate } \\
\text {-Phenylethyl isothiocyanate } \\
\text {-Isopropryl isothiocyanate } \\
\text {-Methyl isothiocyanate } \\
\text { Cinnamon compounds: } \\
\text {-Cinnamaldehyde } \\
\text { Garlic compounds: } \\
\text {-Allicin } \\
\text { Clove bud oil compounds: } \\
\text {-Eugenol } \\
\text { THC }\end{array}$ & $\begin{array}{l}\text {-Inward current } \\
\text {-iCa }{ }^{2+} \text { elevation } \\
\text {-Neuropeptides releases } \\
\text {-Inflammatory mediators release }\end{array}$ & $\begin{array}{l}\text { (Calixto et al., 2005) } \\
\text { (Macpherson et al., 2005) } \\
\text { (Chung et al., 2014) }\end{array}$ \\
\hline $\begin{array}{l}\text { Environmental pollutants: } \\
\text {-Acrolein } \\
\text {-Formalein }\end{array}$ & & $\begin{array}{l}\text { (Bautista et al., 2006) } \\
\text { (McNamara et al., 2007) }\end{array}$ \\
\hline $\begin{array}{l}\text { TRPM8 }{ }^{\mathrm{d}} \text { activators: } \\
\text {-Icilin } \\
\text {-Menthol }\end{array}$ & & (Story et al., 2003) \\
\hline $\begin{array}{l}\text { Histamine-independent pruritogens: } \\
\text {-Chloroquine } \\
- \text { BAM8-22 }^{\mathrm{e}} \\
-\mathrm{AEW}^{\mathrm{f}}\end{array}$ & & $\begin{array}{l}\text { (Imamachi et al., 2009) } \\
\text { (Mishra and Hoon 2010) } \\
\text { (Mishra et al., 2011) } \\
\text { (Wilson et al., 2011, 2013a, b) }\end{array}$ \\
\hline \multicolumn{3}{|l|}{ Endogenous activators of TRPA1: } \\
\hline $\begin{array}{l}\mathrm{ROS}^{\mathrm{g}} \\
\mathrm{NO}^{\mathrm{h}} \\
\text { Lipid oxidation-derived: } \\
-\mathrm{PGA2} 2^{\mathrm{i}} \\
-15 \mathrm{dPGJ2} \\
-\triangle 12-\mathrm{PGJ}^{\mathrm{k}}\end{array}$ & $\begin{array}{l}\text { Direct activation: } \\
\text {-Inward current } \\
-\mathrm{iCa}^{2+} \text { elevation } \\
\text {-Neuropeptides releases } \\
\text {-Inflammatory mediators release }\end{array}$ & $\begin{array}{l}\text { (Pertovaara and Koivisto 2011) } \\
\text { (Bautista et al., 2006) }\end{array}$ \\
\hline $\begin{array}{l}\text { Lipid oxidation products: } \\
-4-\mathrm{HNE}^{\prime} \\
-4-\mathrm{ONE}^{\mathrm{m}}\end{array}$ & & $\begin{array}{l}\text { (Taylor-Clark et al., 2009) } \\
\text { (Engel et al., 2011) }\end{array}$ \\
\hline $\mathrm{DAG}^{\mathrm{n}}$ & & $\begin{array}{l}\text { (Trevisani et al., 2007) } \\
\text { (Bandell et al., 2004) } \\
\text { (Jordt et al., 2004) }\end{array}$ \\
\hline \multicolumn{3}{|l|}{ Indirect activators/sensitizers of TRPA1: } \\
\hline Bradykinin & $\mathrm{BK} 2 \mathrm{R}^{\mathrm{t}}\left(\mathrm{GPCR} \mathrm{R}^{\mathrm{u}}\right)$ & $\begin{array}{l}\text { (Bandell et al., 2004) } \\
\text { (Wang et al., 2008a) }\end{array}$ \\
\hline Growth factors (e.g., NGF $^{\circ}$ and $\mathrm{BDNF}^{\mathrm{p}}$ ) & $\mathrm{RTK}^{\mathrm{v}}$ & (Malin et al., 2011) \\
\hline Proteases & PAR-2 and PAR-4w (GPCR) & $\begin{array}{l}\text { (Dai et al., 2007) } \\
\text { (Patricio et al., 2015) }\end{array}$ \\
\hline Low $\mathrm{iCa}^{2+}$ concentration & EF-hand $\mathrm{Ca}^{2+}$-binding domain & $\begin{array}{l}\text { (Sura et al., 2012) } \\
\text { (Akopian et al., 2007) }\end{array}$ \\
\hline Cytokines (e.g., TSLPq) & TSLP receptor (RTK) & (Wilson et al., 2013a, b) \\
\hline TRPV $^{r}$ & $\begin{array}{l}\text { Physical interaction or } \\
\mathrm{Ca}^{2+} \text { second messenger }\end{array}$ & (Honda et al., 2014) \\
\hline
\end{tabular}


Table 2. continued

\begin{tabular}{|c|c|c|}
\hline Factors & Pathways of activation & References \\
\hline \multicolumn{3}{|c|}{ Inhibitors/desensitizers of TRPA1: } \\
\hline High iCa ${ }^{2+}$ concentration & EF-hand $\mathrm{Ca}^{2+}$-binding domain & $\begin{array}{l}\text { (Sura et al., 2012) } \\
\text { (Wang et al., 2008b) }\end{array}$ \\
\hline $\mathrm{PIP} 2^{\mathrm{s}}$ & Direct binding to TRPA1 & $\begin{array}{l}\text { (Karashima et al., 2008) } \\
\text { (Kim et al., 2008) }\end{array}$ \\
\hline TRPV1 & $\begin{array}{l}\text { Physical interaction or } \\
\mathrm{Ca}^{2+} \text { second messenger }\end{array}$ & $\begin{array}{l}\text { (Akopian et al., 2007) } \\
\text { (Staruschenko et al., 2010) } \\
\text { (Salas et al., 2009) }\end{array}$ \\
\hline
\end{tabular}

Notes: ${ }^{a}$ transient receptor potential ankyrin $1 ;{ }^{b}$ allyl isothiocyanate; ${ }^{c}$ tetrahydrocannabinol; ${ }^{d}$ transient receptor potential melastatin 8 ;

${ }^{\mathrm{e}}$ bovine adrenal medulla $8-22 ;{ }^{\mathrm{f}}$ acetone, ether and water; ${ }^{\mathrm{g}}$ reactive oxygen species; ${ }^{\mathrm{h}}$ nitric oxide; ${ }^{\mathrm{i}}$ prostaglandin $\mathrm{A} 2$;

j 15-deoxy-delta12,14-prostaglandin J2; ${ }^{k} \Delta$ 12-prostaglandin J2; ' 4-hydroxynonenal; ${ }^{\mathrm{m}}$ 4-oxo-2-nonenal; ${ }^{\mathrm{n}}$ diacylglycerol;

${ }^{\circ}$ nerve growth factor; ${ }^{p}$ brain-derived neurotrophic factor; ${ }^{q}$ thymic stromal lymphopoietin; ${ }^{r}$ transient receptor potential vanilloide 1 ;

${ }^{\mathrm{s}}$ phosphatidylinositol 4,5-bisphosphate; ${ }^{\mathrm{t}}$ bradykinin $\mathrm{B} 2$ receptor; ${ }^{\mathrm{u}} \mathrm{G}$ protein-coupled receptor; ${ }^{\mathrm{V}}$ receptor tyrosine kinase;

${ }^{\mathrm{w}}$ protease-activated receptor- 2 and 4.

Macpherson et al., 2007). A EF-hand domain implicated in calcium-dependent gating was also found in its $\mathrm{NH} 2$ region (Zurborg et al., 2007; Doerner et al., 2007). Other specific domains have also been described such as a PIP2 binding site as well as CAMKII and PKC phosphorisation site (Choi et al., 2014). The transmembrane domain $S 6$ are essential for gating by antagonists and agonists (Chen et al., 2008).

\section{$i C a^{2+}$ potentiates TRPA1 activation}

Growing evidence suggests that $\mathrm{Ca}^{2+}$ regulates TRPA1 by potentializing and inactivating its activity at low and high intracellular concentrations, respectively (Jordt et al., 2004; Doerner et al., 2007). On the one hand, $\mathrm{Ca}^{2+}$ potentiated cinnamaldehyde-, AITC-, and carvacrol-evoked currents in HEK293 cells expressing TRPA1. In addition, an increase in $\mathrm{iCa}^{2+}$ also seems to directly act on the activation of TRPA1 by eliciting a current in a PLC-independent manner and serves as a co-agonist with icilin that directly interacts with TRPA1 (Zurborg et al., 2007; Doerner et al., 2007; Wang et al., 2008b). On the other hand, $\mathrm{Ca}^{2+}$ could also inactivate TRPA1. Indeed, even though high extracellular $\mathrm{Ca}^{2+}$ concentrations could enhance a cinnamaldehyde-evoked current, they could also induce rapid inactivation, which has not been found at low extracellular $\mathrm{Ca}^{2+}$ concentrations (Wang et al., 2008b). Hence, $\mathrm{Ca}^{2+}$ appears to be a crucial factor for the regulation of TRPA1 activity, suggesting that other TRP channels and GPCRs could modulate TRPA1 activity by mobilizing $\mathrm{iCa}^{2+}$.

\section{Intracellular sensitizers of TRPA1}

Several studies suggest that TRP channels may be potentiated by endogenous DAG and IP3, the products of PIP2 breakdown, by $\mathrm{Ca}^{2+}$ release from internal stores, by PKC activation or by the formation of endogenous lipid oxidationderived and products in sensory neurons (Wang et al., 2008a; Mizumura et al., 2009). TRPA1-expressing $\mathrm{CHO}$ cells were also sensitive to DAG, arachidonic acid, and $\mathrm{iCa}^{2+}$ (Jordt et al., 2004; Bandell et al., 2004). PIP2 has an inhibitory effect not only on TRPV1 activity (refer to section Intracellular pathways of TRPV1 sensitization) but also on TRPA1 activity, since PIP2 has been shown to inhibit AITCand mustard oil-evoked currents (Kim et al., 2008; Karashima et al., 2008). Moreover, the reduction of the PIP2 level at the membrane by polyphosphatase (e.g., PPPi), PIP2 antibody or phenylarsine oxide enhanced the AITC- and mustard oil-evoked currents via TRPA1 sensitization (Kim et al., 2008; Karashima et al., 2008). Taken together, these data suggest that TRPA 1 activity could be sensitized by the activation of numerous GPCRs or receptor tyrosine kinases (RTKs) via the CAMP/PKA and PLC/PKC pathways following $\mathrm{Ca}^{2+}$ elevation (Taylor-Clark et al., 2008; Andersson et al., 2008; Taylor-Clark et al., 2009)

\section{TRPA1 sensitization by inflammatory mediators}

Several inflammatory mediators, such as growth factors, bradykinins, proteases, and, more recently, the inflammatory cytokine TSLP, have been found to act indirectly on TRPA1 activity and expression through specific receptor-dependent signaling pathways (Diogenes et al., 2007; Dai et al., 2007; Wang et al., 2008a; Malin et al., 2011). It has now been clearly established that TRPA 1 in sensory neurons mediates the CNI responses to bradykinin (Jordt et al., 2004; Bandell et al., 2004; Bautista et al., 2006; Wang et al., 2008a), NGF, and brain-derived neurotrophic factor (BDNF) (Malin et al., 2011) by potentiating the activity of the channel and impairing its desensitization after repeated activation. In addition, NGF has been found to up-regulate the expression of TRPA1 mRNA via p38 MAPK activation in trigeminal ganglia and sensory neurons. Taken together, these mediators enhance the activity and prevent the desensitization of TRPA1 and consequently facilitate pain, hyperalgesia, and allodynia (Obata et al., 2005; Diogenes et al., 2007). TSLP 
released from keratinocytes potentiated TRPA1 activity by binding to its specific receptor (TSLPR) on sensory neurons in the skin of AD patients and in mouse models of AD. While TSLP-evoked sensory neuron activation and consequent chronic itching in AD has been established, the role of TSLPtriggered neuropeptide release in neurons and the subsequent CNI remain an open question (Wilson et al., 2013a, b).

While the involvement of endogenous proteases in TRPV1 sensitization via PAR-2 and PAR-4 activation is well established (refer to section Inflammatory mediators that use TRPV1 intracellular sensitization pathways), the implication of these proteases in TRPA1 sensitization remains poorly understood. PAR2 activation has been demonstrated to enhance TRPA1 agonist-evoked pain behavior in rats via PLC activation and subsequent $\mathrm{PIP}_{2}$ hydrolysis (Dai et al., 2007). In addition, PAR-2-evoked mechanical and cold allodynia, as well as heat hyperalgesia, was found to be dependent on the PKA and PKC signaling pathways, which sensitize TRPA1 (Chen et al., 2011). The involvement of PAR-4 in the sensitization of TRPA1 is poorly studied, but a recent finding demonstrated its potential role in pruritus: the dorsal intradermal administration of the PAR-4 agonist peptide AYPGKF-NH $\mathrm{N}_{2}$ elicited intense scratching behavior via a SP release in mice, which was abolished by the TRPV1 and TRPA1 antagonists SB366791 and HC-030031, respectively (Patricio et al., 2015), but not in TRPA1-deficient mice. An opposite pattern in PAR-4-evoked itching via TRPA1 by compensatory mechanisms in TRPA $1^{-}$deficient mice has been hypothesized (Patricio et al., 2015; Petrus et al., 2007). Consequently, PAR-4 activation could sensitize TRPA1 in collaboration with TRPV1 and elicit itching behavior via the release of neuropeptides from sensory neurons; however, some points still require clarification, mainly the intracellular pathways underlying the TRPV1/TRPA1 sensitization via PAR-4 activation (Patricio et al., 2015).

Finally, the intracellular pathways for many inflammatory mediators could sensitize TRPA1 in injured skin, contributing to channel activity and impairing the TRPA1 desensitization, thereby enhancing peripheral inflammatory responses via the production of other inflammatory mediators.

\section{A pro-inflammatory response induced by TRPA1 activation}

In addition to its ability to induce the release of neuropeptides from sensory neurons, TRPA1 seems to play an important role in the modulation of numerous genes that could amplify the cutaneous inflammatory process. The involvement of TRPA 1 in the regulation of $1,843(2,423$ probe sets) genes in whole trigeminal ganglia isolated from AEW-treated mice has been established (Wilson et al., 2013a). In this model, TRPA1 activation by AEW highly upor down-regulated the expression of several cytokines, plasmatic receptors, and ion channels and affected growth regulation, intracellular pathways, and immune cell specificity proteins. For example, AEW up-regulated the inflammatory bradykinin receptor (BK2R) by 2-fold and upregulated several itch receptors such as MRGPR and PAR-2 in the trigeminal ganglia neurons (Wilson et al., 2013a). These three receptors sensitize and open TRPA1. Thus, the up-regulation of itch and inflammatory receptors in sensory neurons strongly indicates a role for TRPA1 in chronic pruritus and $\mathrm{CNI}$ via the enhancement of sensory neuron sensitivity to itch and inflammatory mediators.

Growing evidence indicates that TRPA1 acts as an inflammatory regulator. The results of recent studies correlated the activation of TRPA1 with expressional changes in the skin, as associated with cutaneous inflammation, $A D$, and pain that is blocked in TRPA1-deficient mice. Indeed, TRPA1 activation by oxazolone induced chronic dermatitis in mouse ears and concomitant up-regulation of inflammatory cytokines (i.e., IL-1 $\beta, \mathrm{IL}-4$, and IL-16 and chemokine (C-X-C motif) ligand 2 (CXCL-2)), neuropeptides (i.e., $S P$ and endothelin (ET-1)), nerve growth factor (NGF), and neurotransmitters (i.e., serotonin) known to induce $A D$, pruritus, and pain and increase nerve fiber density (Liu et al., 2013). Additional studies established the expressional change of 9,340 genes linked to itching associated with TRPA1 in skin biopsies from AEW-treated mice, showing that TRPA1 upregulated the expression of $79 \%$ of itch-related genes known to be involved in the initiation and maintenance of chronic itching as well as pruriginous skin disorders (e.g., the IL-31 receptor (IL-31RA), aquaporin 3, and IL-33 (Wilson et al., 2013a; Nakahigashi et al., 2011; Nobbe et al., 2012; Olsson et al., 2006; Sonkoly et al., 2006). In these studies, the expressional changes induced by oxazolone or AEW were abrogated in the TRPA $1^{-/-}$mice and in WT mice treated with TRPA1 antagonists (Wilson et al., 2013a; Liu et al., 2013). These data strongly suggest the involvement of TRPA1 in pruritus.

TRPA1 is also expressed in the basal keratinocytes, where it acts as a pain, thermal, and chemical sensor (Atoyan et al., 2009). TRPA1 was found to modulate inflammatory gene expression in keratinocytes by increasing the expression of IL-1 $\alpha$ and IL-1 $\beta$ (Atoyan et al., 2009) and cause the secretion of PgE2 (Jain et al., 2011). Both IL-1 and $\mathrm{PgE} 2$ are known to be involved in skin inflammation and itching by decreasing the mechanical threshold and the thermal responsiveness of the sensory nerve endings, which could facilitate CNI (Binshtok et al., 2008). In addition, in keratinocytes, TRPA1 activation increases heat shock protein (HSP) 27, which is known to up-regulate the expression of inflammatory cytokines such as IL-1 $\beta$, TNF- $\alpha$, and IL- 6 in the skin during murine allergic contact hypersensitivity (Yusuf et al., 2009; Atoyan et al., 2009). Altogether, these findings indicate that TRPA1 activation contributes to the production of several cytokines from keratinocytes that directly trigger or enhance $\mathrm{CNI}$ by acting on neighboring target cells.

In addition to keratinocytes, TRPA1 acts on skin immune cells, but it appears to have an anti-inflammatory role in monocytes/macrophages. The TRPA1 activators cinnamaldehyde 
and carvacol have been found to inhibit bacterial lipopolysaccharides (LPS)-induced nuclear factor-kappa B (NF-kB)-mediated promoter activity and reduce the expression of iNOS, COX2, and TNF- $\alpha$ and subsequent NO production in macrophages (Chao et al., 2008; Romano et al., 2013). Similarly, cinnamaldehyde inhibited bacterial LPS- and lipoteichoic acid (LTA)-mediated IL-1 $\beta$, IL-6, and TNF- $\alpha$ release in murine macrophages and human blood monocytes, presumably through ROS production (Hsu and Wen 2002; Chao et al., 2008; Romano et al., 2013). Furthermore, an increase in TNF- $\alpha$ as well as the induction of both kinnitric oxide synthases (iNOS) and COX2, which are involved in the formation of NO and PGE2, respectively, are known to act in the pathogenesis of several inflammatory skin diseases, such as $A D$, psoriasis, and pruritus (Ormerod et al., 1998; Kim et al., 2015; Ostadhadi et al., 2015; Ahn et al., 2016; Sereflican et al., 2016). It would therefore appear that TRPA1 acts as an anti-inflammatory actor in monocytes and macrophages, but these data are controversial (Billeter et al., 2015). The activation of TRPA1 by cinnamaldehyde acts on adaptive immunity by suppressing lymphoproliferation and promoting T-cell maturation, as revealed by T-cell differentiation from CD4 and CD8 double-positive cells to CD4 or CD8 single-positive cells in LPS-treated mouse splenocytes (Koh et al., 1998). These results imply that TRPA1 could enhance inflammation and immunoreactivity by directly acting on lymphocyte differentiation.

TRPA1 activation by AITC has been found to trigger vasodilatation in rat cerebral arteries in an endothelium-dependent mechanism. TRPA1-mediated vasodilation triggers $\mathrm{Ca}^{2+}$ influx in rat endothelial arteries through $\mathrm{Ca}^{2+}$-activated potassium channels in endothelial cells and inwardly rectifying potassium channels in arterial myocytes (Earley et al., 2009; Qian et al., 2013). This mechanism suggests that this channel could also act in edema and vasodilatation during $\mathrm{CNI}$, but this hypothesis must be verified. However, another study established that TRPA1 activation by cinnamaldehyde played an anti-inflammatory role by suppressing the attachment of leukocytes to endothelial cells (Liao et al., 2008).

To conclude, TRPA1 activation and sensitization mediate skin inflammation by increasing the release of inflammatory mediators, although their role in immune cells remains to be clarified. In turn, secreted factors mediate the intracellular sensitization of TRPA1, thus facilitating its activation, which in turn contributes to enhancement of the self-maintenance of CNI.

\section{CROSS-REGULATION BETWEEN TRPV1 AND TRPA1}

In addition to co-expression in a subset of sensory nerves and non-neuronal cells (keratinocytes), a functional interaction between TRPA1 and TRPV1 (cross-sensitization/desensitization) has been established, which suggests the cooperation between these channels to promote inflammatory thermal hyperalgesia, $\mathrm{CNI}$, and pain (Bautista et al.,
2006; Akopian et al., 2007; Anand et al., 2008; Patil et al., 2010; Aubdool and Brain 2011; Spahn et al., 2014; Fischer et al., 2014).

This cross-communication between TRPA1 and TRPV1 appears to involve the concentration of cytosolic $\mathrm{Ca}^{2+}$, one of the main sensitizers/desensitizers of TRPA1 and TRPV1 (Jordt et al., 2004; Jung et al., 2004; Doerner et al., 2007; Woo et al., 2008). It has been shown that capsaicin- and mustard oil-evoked currents desensitized each other via $\mathrm{iCa}^{2+}$ elevation in TRPV1- and/or TRPA1-expressing $\mathrm{CHO}$ cells (Akopian et al., 2007). Another relevant study confirmed the role of the influx of $\mathrm{Ca}^{2+}$ via TRPV1 as a second messenger for the desensitization of TRPA1. Indeed, TRPA1 evoked a current in $\mathrm{CHO}$ cells expressing TRPA1, and this current was inhibited by the co-expression of TRPV1 (Patil et al., 2010). In addition, TRPA1 and TRPV1 were found to interact by forming a physical and functional interaction at the plasma membrane, as revealed by co-IP and FRET assays in TRPA1- and TRPV1-co-expressing $\mathrm{CHO}$ cells, as well as in sensory neurons (Akopian et al., 2007; Salas et al., 2009; Staruschenko et al., 2010; Fischer et al., 2014). In these cells, TRPV1 regulated the desensitization of TRPA1, which appeared to be independent of $\mathrm{iCa}^{2+}$ (Staruschenko et al., 2010).

On the other hand, evidence has established that the TRPV1 and TRPA1 channels also sensitize each other in a $\mathrm{Ca}^{2+}$-dependent signaling pathway. Indeed, bradykinin and facial capsaicin injections sensitized TRPA1 via TRPV1 in a $\mathrm{Ca}^{2+}$-dependent manner in cultured trigeminal neurons from mice and rats, leading to inflammatory cold hyperalgesia (Bautista et al., 2006; Honda et al., 2014). The opposite pattern was also found: TRPA1 could sensitize TRPV1 to AITC-, cinnamaldehyde-, and mustard oil-enhanced heatand capsaicin-evoked currents and $\mathrm{Ca}^{2+}$ elevation in a $\mathrm{Ca}^{2+}$-, cAMP/PKA-, and TRPV1 phosphorylation-dependent manner in sensory neurons and in HEK293 cells co-expressing TRPV1 and TRPA1 (Anand et al., 2008; Alpizar et al., 2013; Spahn et al., 2014).

Altogether, the TRPV1-TRPA1 interaction and crosscommunication via the $\mathrm{iCa}^{2+}$ concentration could inhibit or enhance the ability to a large variety of exogenous and endogenous activators to cause $\mathrm{Ca}^{2+}$ elevation, neuropeptide release and, consequently, CNI.

\section{CONCLUSIONS AND FUTURE DIRECTIONS}

The TRPV1 and TRPA1 channels are at the core of the inflammatory process that occurs in various cutaneous neurogenic disorders that are pruritic diseases, such as psoriasis, $A D$, and Netherton syndrome. It is now clear that both TRP channels act far beyond the sensory nerves by potentiating the pathology of numerous skin disorders in non-neuronal skin cells, such as keratinocytes, mast cells, dendritic cells, and blood vessels. We still have a great deal to learn about these channels, notably about the change of gene expression in sensory neurons and non-neuronal skin 
cells, especially in relation to their role in the induction and self-maintenance of $\mathrm{CNI}$ (in vitro and in vivo). A great deal of knowledge about their interaction, their cross-sensitization, and their sensitization by inflammatory mediators awaits discovery, especially in relation to the potentiation and the chronicitization of skin disorders associated with CNI. Although the molecular mechanisms of TRPV1 and TRPA1 sensitization induced during $\mathrm{CNI}$ and itching are still poorly understood, their clinical relevance in pruritus, inflammatory thermal hyperalgesia, and pain are indisputable.

Targeting one or more of the intracellular signaling pathways of TRP channel sensitization may allow new opportunities for the treatment of skin disorders associated with CNI. Further studies are necessary to test the potential effects of treatment with protein signaling inhibitors in neurogenic inflamed skin. A new and interesting approach could also be to focus on the effect of the $\mathrm{iCa}^{2+}$ concentration to mediate TRP desensitization and thus block the self-maintenance of CNI.

\section{ACKNOWLEDGEMENTS}

This work was supported by the Uriage Dermatological Laboratories, Courbevoie, France. The authors wish to thank the entire team of the Laboratory of Neurosciences of Brest (EA4685). O.G. has received research grants from Uriage. NL has received research grants from BASF, Johnson \& Johnson. C.L.G.I. has received research grants from Beiersdorf, Clarins, L'Oréal, Natura, Pierre Fabre. L.L. has worked for Uriage. L.M. has received research grants from Almirall, BASF, Beiersdorf, Bioderma, Celgene, Clarins, Expanscience, Galderma, Johnson \& Johnson, L'Oréal, Natura, Pierre Fabre, Sofibel, Solabia, Uriage.

\section{ABBREVIATIONS}

12-HETE, 12-hydroxyeicosatetraenoic; AD, atopic dermatitis; BDNF, brain-derived neurotrophic factor; CAMKII, $\mathrm{Ca}^{2+} /$ calmodulin dependent kinase II; CGRP, calcitonin gene-related peptide; CNI, cutaneous neurogenic inflammation; COX-2, cyclo-oxygenase-2; cryoEM, cryo-electron microscopy; DAG, diacylglycerol; DCs, dendritic cells; DRG, dorsal root ganglion; eNOS, endothelial nitric oxide synthase; GPCRs, G protein-coupled receptors; HSP, heat shock protein; $\mathrm{iCa}^{2+}$, intracellular $\mathrm{Ca}^{2+}$ concentration; IL, interleukin; LPS, lipopolysaccharides; LTA, lipoteichoic acid; MMPs, matrix metalloproteinases; NF-kB, nuclear factor-kappa B; NGF, nerve growth factor; PAR, protease-activated receptor; PG, prostaglandins; PIP2, phosphatidylinositol 4,5-bisphosphate; PKA, protein kinases $A$; PKC, protein kinases C; PLA2, phospholipase A2; PLC, phospholipase C; RTKs, receptor tyrosine kinases; SP, substance P; TNF- $\alpha$, tumor necrosis factor- $\alpha$, TRP, transient receptor potential; TRPA1, transient receptor potential ankyrin 1; TRPV1, transient receptor potential vanilloid 1; TSLP, thymic stromal lymphopoietin; UV, ultraviolet

\section{COMPLIANCE WITH ETHICS GUIDELINES}

The authors declare that they have no conflict of interest.

\section{AUTHORS' CONTRIBUTIONS}

O.G. drafted the manuscript. R.L.G., K.L., N.L., C.L.G.I., and L.M. helped to draft the manuscript. All authors reviewed and agreed to the final version of the manuscript.

\section{OPEN ACCESS}

This article is distributed under the terms of the Creative Commons Attribution 4.0 International License (http://creativecommons.org/ licenses/by/4.0/), which permits unrestricted use, distribution, and reproduction in any medium, provided you give appropriate credit to the original author(s) and the source, provide a link to the Creative Commons license, and indicate if changes were made.

\section{REFERENCES}

Ahn S, Siddiqi MH, Aceituno VC et al (2016) Ginsenoside Rg5:Rk1 attenuates TNF- $\alpha / \mathrm{IFN}-\mathrm{\gamma}$-induced production of thymus- and activation-regulated chemokine (TARC/CCL17) and LPS-induced NO production via downregulation of NF-KB/p38 MAPK/STAT1 signaling in human keratinocytes and macrophages. In Vitro Cell Dev Biol Anim 52:287-295. doi:10.1007/s11626-015-9983-y

Akaishi S, Ogawa R, Hyakusoku H (2008) Keloid and hypertrophic scar: neurogenic inflammation hypotheses. Med Hypotheses 71:32-38. doi:10.1016/j.mehy.2008.01.032

Akiyama T, Ivanov M, Nagamine M et al (2016) Involvement of TRPV4 in serotonin-evoked scratching. J Invest Dermatol 136:154-160. doi:10.1038/JID.2015.388

Akopian AN, Ruparel NB, Jeske NA, Hargreaves KM (2007) Transient receptor potential TRPA1 channel desensitization in sensory neurons is agonist dependent and regulated by TRPV1directed internalization. J Physiol 583:175-193. doi:10.1113/ jphysiol.2007.133231

Alpizar YA, Boonen B, Gees M et al (2013) Allyl isothiocyanate sensitizes TRPV1 to heat stimulation. Pflüg Arch—Eur J Physiol 466:507-515. doi:10.1007/s00424-013-1334-9

Amadesi S, Nie J, Vergnolle N et al (2004) Protease-activated receptor 2 sensitizes the capsaicin receptor transient receptor potential vanilloid receptor 1 to induce hyperalgesia. J Neurosci Off J Soc Neurosci 24:4300-4312. doi:10.1523/JNEUROSCI. 5679-03.2004

Amadesi S, Cottrell GS, Divino L et al (2006) Protease-activated receptor 2 sensitizes TRPV1 by protein kinase $\mathrm{C} \varepsilon$ - and A-dependent mechanisms in rats and mice. J Physiol 575:555-571. doi:10.1113/jphysiol.2006.111534

Anand U, Otto WR, Facer P et al (2008) TRPA1 receptor localisation in the human peripheral nervous system and functional studies in cultured human and rat sensory neurons. Neurosci Lett 438:221227. doi:10.1016/j.neulet.2008.04.007

Andersson DA, Gentry C, Moss S, Bevan S (2008) Transient receptor potential $A 1$ is a sensory receptor for multiple products of oxidative stress. J Neurosci Off J Soc Neurosci 28:2485-2494. doi:10.1523/JNEUROSCI.5369-07.2008 
Andreev YA, Vassilevski AA, Kozlov SA (2012) Molecules to selectively target receptors for treatment of pain and neurogenic inflammation. Recent Pat Inflamm Allergy Drug Discov 6:35-45

Asfaha S, Cenac N, Houle S et al (2007) Protease-activated receptor-4: a novel mechanism of inflammatory pain modulation. Br J Pharmacol 150:176-185. doi:10.1038/sj.bjp.0706975

Atoyan R, Shander D, Botchkareva NV (2009) Non-neuronal expression of transient receptor potential type A1 (TRPA1) in human skin. J Invest Dermatol 129:2312-2315. doi:10.1038/jid. 2009.58

Aubdool AA, Brain SD (2011) Neurovascular aspects of skin neurogenic inflammation. J Investig Dermatol Symp Proc Soc Investig Dermatol Inc Eur Soc Dermatol Res 15:33-39. doi:10. 1038/jidsymp.2011.8

Bandell M, Story GM, Hwang SW et al (2004) Noxious cold ion channel TRPA1 is activated by pungent compounds and bradykinin. Neuron 41:849-857

Basu S, Srivastava P (2005) Immunological role of neuronal receptor vanilloid receptor 1 expressed on dendritic cells. Proc Natl Acad Sci U S A 102:5120-5125. doi:10.1073/pnas.0407780102

Bautista DM, Jordt S-E, Nikai T et al (2006) TRPA1 mediates the inflammatory actions of environmental irritants and proalgesic agents. Cell 124:1269-1282. doi:10.1016/j.cell.2006.02.023

Bautista DM, Pellegrino M, Tsunozaki M (2013) TRPA1: A gatekeeper for inflammation. Annu Rev Physiol 75:181-200. doi:10. 1146/annurev-physiol-030212-183811

Bhave G, Zhu W, Wang $\mathrm{H}$ et al (2002) cAMP-dependent protein kinase regulates desensitization of the capsaicin receptor (VR1) by direct phosphorylation. Neuron 35:721-731

Bhave G, Hu H-J, Glauner KS et al (2003) Protein kinase C phosphorylation sensitizes but does not activate the capsaicin receptor transient receptor potential vanilloid 1 (TRPV1). Proc Natl Acad Sci U S A 100:12480-12485. doi:10.1073/pnas. 2032100100

Billeter AT, Galbraith N, Walker S et al (2015) TRPA1 mediates the effects of hypothermia on the monocyte inflammatory response. Surgery 158:646-654. doi:10.1016/j.surg.2015.03.065

Binshtok AM, Wang $\mathrm{H}$, Zimmermann $\mathrm{K}$ et al (2008) Nociceptors are interleukin-1 $\beta$ sensors. J Neurosci Off J Soc Neurosci 28:1406214073. doi:10.1523/JNEUROSCI.3795-08.2008

Bíró T, Kovács L (2009) An "ice-cold" TR(i)P to skin biology: the role of TRPA1 in human epidermal keratinocytes. J Invest Dermatol 129:2096-2099. doi:10.1038/jid.2009.179

Bíró T, Maurer M, Modarres $S$ et al (1998) Characterization of functional vanilloid receptors expressed by mast cells. Blood 91:1332-1340

Boillat A, Alijevic O, Kellenberger S (2014) Calcium entry via TRPV1 but not ASICs induces neuropeptide release from sensory neurons. Mol Cell Neurosci 61C:13-22. doi:10.1016/j.mcn. 2014.04.007

Briot A, Deraison C, Lacroix M et al (2009) Kallikrein 5 induces atopic dermatitis-like lesions through PAR2-mediated thymic stromal lymphopoietin expression in Netherton syndrome. J Exp Med 206:1135-1147. doi:10.1084/jem.20082242

Bunker CB, Cerio R, Bull HA et al (1991) The effect of capsaicin application on mast cells in normal human skin. Agents Actions 33:195-196
Burgess GM, Mullaney I, McNeill M et al (1989) Second messengers involved in the mechanism of action of bradykinin in sensory neurons in culture. J Neurosci 9:3314-3325

Calixto JB, Kassuya CAL, André E, Ferreira J (2005) Contribution of natural products to the discovery of the transient receptor potential (TRP) channels family and their functions. Pharmacol Ther 106:179-208. doi:10.1016/j.pharmthera.2004.11.008

Caterina MJ, Schumacher MA, Tominaga M et al (1997) The capsaicin receptor: a heat-activated ion channel in the pain pathway. Nature 389:816-824. doi:10.1038/39807

Cesare P, Moriondo A, Vellani V, McNaughton PA (1999) Ion channels gated by heat. Proc Natl Acad Sci U S A 96:7658-7663

Chao LK, Hua K-F, Hsu H-Y et al (2008) Cinnamaldehyde inhibits pro-inflammatory cytokines secretion from monocytes/macrophages through suppression of intracellular signaling. Food Chem Toxicol Int J Publ Br Ind Biol Res Assoc 46:220231. doi:10.1016/j.fct.2007.07.016

Chen J, Zhang X-F, Kort ME et al (2008) Molecular determinants of species-specific activation or blockade of TRPA1 channels. J Neurosci 28:5063-5071. doi:10.1523/JNEUROSCI.0047-08. 2008

Chen Y, Yang C, Wang ZJ (2011) Proteinase-activated receptor 2 sensitizes transient receptor potential vanilloid 1 , transient receptor potential vanilloid 4 , and transient receptor potential ankyrin 1 in paclitaxel-induced neuropathic pain. Neuroscience 193:440-451. doi:10.1016/j.neuroscience.2011.06.085

Chen D, Wang Z, Zhang Z et al (2013) Capsaicin up-regulates protease-activated receptor-4 mRNA and protein in primary cultured dorsal root ganglion neurons. Cell Mol Neurobiol 33:337-346. doi:10.1007/s10571-012-9899-y

Ching L-C, Kou YR, Shyue S-K et al (2011) Molecular mechanisms of activation of endothelial nitric oxide synthase mediated by transient receptor potential vanilloid type 1. Cardiovasc Res 91:492-501. doi:10.1093/cvr/cvr104

Choi S-I, Yoo S, Lim JY, Hwang SW (2014) Are sensory TRP channels biological alarms for lipid peroxidation? Int J Mol Sci 15:16430-16457. doi:10.3390/ijms150916430

Chuang $\mathrm{HH}$, Prescott ED, Kong $\mathrm{H}$ et al (2001) Bradykinin and nerve growth factor release the capsaicin receptor from Ptdlns(4,5)P2mediated inhibition. Nature 411:957-962. doi:10.1038/35082088

Chung G, Im ST, Kim YH et al (2014) Activation of transient receptor potential ankyrin 1 by eugenol. Neuroscience 261:153-160. doi:10.1016/j.neuroscience.2013.12.047

Cocks TM, Moffatt JD (2000) Protease-activated receptors: sentries for inflammation? Trends Pharmacol Sci 21:103-108. doi:10. 1016/S0165-6147(99)01440-6

Costa A, Eberlin S, Polettini AJ et al (2014) Neuromodulatory and anti-inflammatory ingredient for sensitive skin: in vitro assessment. Inflamm Allergy Drug Targets 13:191-198

Dai Y, Moriyama T, Higashi T et al (2004) Proteinase-activated receptor 2-mediated potentiation of transient receptor potential vanilloid subfamily 1 activity reveals a mechanism for proteinaseinduced inflammatory pain. J Neurosci Off J Soc Neurosci 24:4293-4299. doi:10.1523/JNEUROSCI.0454-04.2004

Dai Y, Wang S, Tominaga M et al (2007) Sensitization of TRPA1 by PAR2 contributes to the sensation of inflammatory pain. J Clin Invest 117:1979-1987. doi:10.1172/JCI30951 
Diogenes A, Akopian AN, Hargreaves KM (2007) NGF up-regulates TRPA1: implications for orofacial pain. J Dent Res 86:550-555

Docherty RJ, Yeats JC, Bevan S, Boddeke HW (1996) Inhibition of calcineurin inhibits the desensitization of capsaicin-evoked currents in cultured dorsal root ganglion neurones from adult rats. Pflüg Arch Eur J Physiol 431:828-837

Doerner JF, Gisselmann G, Hatt H, Wetzel CH (2007) Transient receptor potential channel $A 1$ is directly gated by calcium ions. J Biol Chem 282:13180-13189. doi:10.1074/jbc.M607849200

Earley S, Gonzales AL, Crnich R (2009) Endothelium-dependent cerebral artery dilation mediated by TRPA1 and Ca2+-Activated $\mathrm{K}+$ channels. Circ Res 104:987-994. doi:10.1161/ CIRCRESAHA.108.189530

Engel MA, Leffler A, Niedermirtl F et al (2011) TRPA1 and substance $P$ mediate colitis in mice. Gastroenterology 141:1346-1358. doi:10.1053/j.gastro.2011.07.002

Fischer MJM, Balasuriya D, Jeggle P et al (2014) Direct evidence for functional TRPV1/TRPA1 heteromers. Pflugers Arch. doi:10. 1007/s00424-014-1497-z

Frydas S, Varvara G, Murmura G et al (2013) Impact of capsaicin on mast cell inflammation. Int J Immunopathol Pharmacol 26:597600

Fu Q, Cheng J, Gao Y et al (2014) Protease-activated receptor 4: a critical participator in inflammatory response. Inflammation. doi:10.1007/s10753-014-9999-6

Gouin O, Lebonvallet N, L'Herondelle K et al (2015) Self-maintenance of neurogenic inflammation contributes to a vicious cycle in skin. Exp Dermatol. doi:10.1111/exd.12798

Herbert MK, Holzer P (2002) Neurogenic inflammation. I. Basic mechanisms, physiology and pharmacology. Anästhesiol Intensivmed Notfallmedizin Schmerzther AINS 37:314-325. doi:10. 1055/s-2002-32233

Himi N, Hamaguchi A, Hashimoto $\mathrm{K}$ et al (2012) Calcium influx through the TRPV1 channel of endothelial cells (ECs) correlates with a stronger adhesion between monocytes and ECs. Adv Med Sci 57:224-229. doi:10.2478/v10039-012-0044-4

Hinman A, Chuang H-H, Bautista DM, Julius D (2006) TRP channel activation by reversible covalent modification. Proc Natl Acad Sci U S A 103:19564-19568. doi:10.1073/pnas.0609598103

Honda K, Shinoda M, Furukawa A et al (2014) TRPA1 contributes to capsaicin-induced facial cold hyperalgesia in rats. Eur J Oral Sci. doi:10.1111/eos.12157

Hoogerwerf WA, Zou L, Shenoy M et al (2001) The proteinaseactivated receptor 2 is involved in nociception. $\mathrm{J}$ Neurosci Off $\mathrm{J}$ Soc Neurosci 21:9036-9042

Horváth G, Kemény Á, Barthó L et al (2015) Effects of some natural carotenoids on TRPA1- and TRPV1-induced neurogenic inflammatory processes in vivo in the mouse skin. J Mol Neurosci MN. doi:10.1007/s12031-014-0472-7

Hsu H-Y, Wen M-H (2002) Lipopolysaccharide-mediated reactive oxygen species and signal transduction in the regulation of interleukin-1 gene expression. J Biol Chem 277:22131-22139. doi:10.1074/jbc.M111883200

Huang L-YM, Neher E (1996) $\mathrm{Ca}^{2+}$-dependent exocytosis in the somata of dorsal root ganglion neurons. Neuron 17:135-145. doi:10.1016/S0896-6273(00)80287-1
Huang SM, Bisogno T, Trevisani M et al (2002) An endogenous capsaicin-like substance with high potency at recombinant and native vanilloid VR1 receptors. Proc Natl Acad Sci U S A 99:8400-8405. doi:10.1073/pnas.122196999

Huang J, Stohl LL, Zhou X et al (2011) Calcitonin gene-related peptide inhibits chemokine production by human dermal microvascular endothelial cells. Brain Behav Immun 25:787799. doi:10.1016/j.bbi.2011.02.007

Hwang SW, Cho H, Kwak J et al (2000) Direct activation of capsaicin receptors by products of lipoxygenases: endogenous capsaicinlike substances. Proc Natl Acad Sci U S A 97:6155-6160

Imamachi N, Park GH, Lee $\mathrm{H}$ et al (2009) TRPV1-expressing primary afferents generate behavioral responses to pruritogens via multiple mechanisms. Proc Natl Acad Sci U S A 106:1133011335. doi:10.1073/pnas.0905605106

Inoue K, Koizumi S, Fuziwara S et al (2002) Functional vanilloid receptors in cultured normal human epidermal keratinocytes. Biochem Biophys Res Commun 291:124-129. doi:10.1006/bbrc. 2002.6393

Jain A, Brönneke S, Kolbe L et al (2011) TRP-channel-specific cutaneous eicosanoid release patterns. Pain 152:2765-2772. doi:10.1016/j.pain.2011.08.025

Jancsó N, Jancsó-Gábor A, Szolcsányi J (1967) Direct evidence for neurogenic inflammation and its prevention by denervation and by pretreatment with capsaicin. $\mathrm{Br} \mathrm{J}$ Pharmacol Chemother 31:138-151

Jans R, Sartor M, Jadot M, Poumay Y (2004) Calcium entry into keratinocytes induces exocytosis of lysosomes. Arch Dermatol Res 296:30-41. doi:10.1007/s00403-004-0469-0

Jeske NA, Patwardhan AM, Gamper N et al (2006) Cannabinoid WIN 55,212-2 regulates TRPV1 phosphorylation in sensory neurons. J Biol Chem 281:32879-32890. doi:10.1074/jbc. M603220200

Jia X, Zhang H, Cao X et al (2014) Activation of TRPV1 mediates thymic stromal lymphopoietin release via the $\mathrm{Ca}^{2+} / \mathrm{NFAT}$ pathway in airway epithelial cells. FEBS Lett 588:3047-3054. doi:10.1016/ j.febslet.2014.06.018

Jian T, Yang N, Yang Y et al (2016) TRPV1 and PLC participate in histamine H4 receptor-induced itch. Neural Plast 2016:1682972. doi:10.1155/2016/1682972

Jordt S-E, Bautista DM, Chuang $\mathrm{H}-\mathrm{H}$ et al (2004) Mustard oils and cannabinoids excite sensory nerve fibres through the TRP channel ANKTM1. Nature 427:260-265. doi:10.1038/ nature02282

Jung J, Shin JS, Lee S-Y et al (2004) Phosphorylation of vanilloid receptor 1 by $\mathrm{Ca}^{2+} /$ calmodulin-dependent kinase II regulates its vanilloid binding. J Biol Chem 279:7048-7054. doi:10.1074/jbc. M311448200

Karashima Y, Prenen J, Meseguer V et al (2008) Modulation of the transient receptor potential channel TRPA 1 by phosphatidylinositol 4,5-biphosphate manipulators. Pflüg Arch Eur J Physiol 457:77-89. doi:10.1007/s00424-008-0493-6

Kark T, Bagi Z, Lizanecz E et al (2008) Tissue-specific regulation of microvascular diameter: opposite functional roles of neuronal and smooth muscle located vanilloid receptor-1. Mol Pharmacol 73:1405-1412. doi:10.1124/mol.107.043323 
Kim D, Cavanaugh EJ, Simkin D (2008) Inhibition of transient receptor potential A1 channel by phosphatidylinositol-4,5-bisphosphate. Am J Physiol Cell Physiol 295:C92-99. doi:10.1152/ ajpcell.00023.2008

Kim CG, Kang M, Lee Y-H et al (2015) Bathing effects of various seawaters on allergic (atopic) dermatitis-like skin lesions induced by 2,4-dinitrochlorobenzene in hairless mice. Evid-Based Complement Altern Med ECAM 2015:179185. doi:10.1155/2015/ 179185

Kim S, Barry DM, Liu X-Y et al (2016) Facilitation of TRPV4 by TRPV1 is required for itch transmission in some sensory neuron populations. Sci Signal 9:ra71. doi:10.1126/scisignal.aaf1047

Koh WS, Yoon SY, Kwon BM et al (1998) Cinnamaldehyde inhibits lymphocyte proliferation and modulates T-cell differentiation. Int J Immunopharmacol 20:643-660

Kubanov AA, Katunina OR, Chikin VV (2015) Expression of neuropeptides, neurotrophins, and neurotransmitters in the skin of patients with atopic dermatitis and psoriasis. Bull Exp Biol Med 159:318-322. doi:10.1007/s10517-015-2951-4

Kürkçüoğlu N, Alaybeyi F (1991) Substance P immunoreactivity in rosacea. J Am Acad Dermatol 25:725-726

Kwak IS, Choi YH, Jang YC, Lee YK (2014) Immunohistochemical analysis of neuropeptides (protein gene product 9.5, substance $P$ and calcitonin gene-related peptide) in hypertrophic burn scar with pain and itching. Burns 40:1661-1667. doi:10.1016/j.burns. 2014.04.004

Lee YM, Kim YK, Kim KH et al (2009) A novel role for the TRPV1 channel in UV-induced matrix metalloproteinase (MMP)-1 expression in HaCaT cells. J Cell Physiol 219:766-775. doi:10.1002/jcp. 21729

Lee YM, Kang SM, Lee SR et al (2011) Inhibitory effects of TRPV1 blocker on UV-induced responses in the hairless mice. Arch Dermatol Res 303:727-736. doi:10.1007/s00403-011-1153-9

Liao B-C, Hsieh C-W, Liu Y-C et al (2008) Cinnamaldehyde inhibits the tumor necrosis factor- $\alpha$-induced expression of cell adhesion molecules in endothelial cells by suppressing NF-KB activation: Effects upon IkB and Nrf2. Toxicol Appl Pharmacol 229:161-171. doi:10.1016/j.taap.2008.01.021

Liao M, Cao E, Julius D, Cheng Y (2013) Structure of the TRPV1 ion channel determined by electron cryo-microscopy. Nature 504:107-112. doi:10.1038/nature12822

Lin Z, Chen $Q$, Lee $M$ et al (2012) Exome sequencing reveals mutations in TRPV3 as a cause of Olmsted syndrome. Am J Hum Genet 90:558-564. doi:10.1016/j.ajhg.2012.02.006

Liu B, Escalera J, Balakrishna S et al (2013) TRPA1 controls inflammation and pruritogen responses in allergic contact dermatitis. FASEB J Off Publ Fed Am Soc Exp Biol 27:3549-3563. doi:10.1096/fj.13-229948

Luo D, Zhang Y-W, Peng W-J et al (2008) Transient receptor potential vanilloid 1-mediated expression and secretion of endothelial cell-derived calcitonin gene-related peptide. Regul Pept 150:66-72. doi:10.1016/j.regpep.2008.05.007

Macpherson LJ, Geierstanger BH, Viswanath V et al (2005) The pungency of garlic: activation of TRPA1 and TRPV1 in response to allicin. Curr Biol CB 15:929-934. doi:10.1016/j.cub.2005.04. 018
Macpherson LJ, Dubin AE, Evans MJ et al (2007) Noxious compounds activate TRPA1 ion channels through covalent modification of cysteines. Nature 445:541-545. doi:10.1038/ nature05544

Malin S, Molliver D, Christianson JA et al (2011) TRPV1 and TRPA1 function and modulation are target tissue dependent. J Neurosci Off J Soc Neurosci 31:10516-10528. doi:10.1523/JNEUROSCI. 2992-10.2011

McNamara CR, Mandel-Brehm J, Bautista DM et al (2007) TRPA1 mediates formalin-induced pain. Proc Natl Acad Sci U S A 104:13525-13530. doi:10.1073/pnas.0705924104

Meseguer V, Alpizar YA, Luis E et al (2014) TRPA1 channels mediate acute neurogenic inflammation and pain produced by bacterial endotoxins. Nat Commun 5:3125. doi:10.1038/ ncomms 4125

Mishra SK, Hoon MA (2010) Ablation of TrpV1 neurons reveals their selective role in thermal pain sensation. Mol Cell Neurosci 43:157-163. doi:10.1016/j.mcn.2009.10.006

Mishra SK, Tisel SM, Orestes P et al (2011) TRPV1-lineage neurons are required for thermal sensation. EMBO J 30:582-593. doi:10. 1038/emboj.2010.325

Mizumura K, Sugiura T, Katanosaka K et al (2009) Excitation and sensitization of nociceptors by bradykinin: what do we know? Exp Brain Res 196:53-65. doi:10.1007/s00221-009-1814-5

Mohapatra DP, Nau C (2003) Desensitization of capsaicin-activated currents in the vanilloid receptor TRPV1 is decreased by the cyclic AMP-dependent protein kinase pathway. J Biol Chem 278:50080-50090. doi:10.1074/jbc.M306619200

Mohapatra DP, Nau C (2005) Regulation of $\mathrm{Ca}^{2+}$-dependent desensitization in the vanilloid receptor TRPV1 by calcineurin and cAMP-dependent protein kinase. J Biol Chem 280:1342413432. doi:10.1074/jbc.M410917200

Moniaga CS, Jeong SK, Egawa G et al (2013) Protease activity enhances production of thymic stromal lymphopoietin and basophil accumulation in flaky tail mice. Am J Pathol 182:841851. doi:10.1016/j.ajpath.2012.11.039

Nakahigashi K, Kabashima K, Ikoma A et al (2011) Upregulation of aquaporin-3 is involved in keratinocyte proliferation and epidermal hyperplasia. J Invest Dermatol 131:865-873. doi:10.1038/jid. 2010.395

Nakanishi M, Hata K, Nagayama T et al (2010) Acid activation of Trpv1 leads to an up-regulation of calcitonin gene-related peptide expression in dorsal root ganglion neurons via the CaMK-CREB cascade: a potential mechanism of inflammatory pain. Mol Biol Cell 21:2568-2577. doi:10.1091/mbc.E10-01-0049

Nobbe S, Dziunycz P, Mühleisen B et al (2012) IL-31 expression by inflammatory cells is preferentially elevated in atopic dermatitis. Acta Derm Venereol 92:24-28. doi:10.2340/00015555-1191

Numazaki M, Tominaga T, Toyooka H, Tominaga M (2002) Direct phosphorylation of capsaicin receptor VR1 by protein kinase Cepsilon and identification of two target serine residues. J Biol Chem 277:13375-13378. doi:10.1074/jbc.C200104200

Obata K, Katsura H, Mizushima T et al (2005) TRPA1 induced in sensory neurons contributes to cold hyperalgesia after inflammation and nerve injury. J Clin Invest 115:2393-2401. doi:10. $1172 / \mathrm{JCl} 25437$ 
Olsson M, Broberg A, Jernås M et al (2006) Increased expression of aquaporin 3 in atopic eczema. Allergy 61:1132-1137. doi:10. 1111/j.1398-9995.2006.01151.x

Oprée A, Kress M (2000) Involvement of the proinflammatory cytokines tumor necrosis factor-alpha, IL-1 beta, and IL-6 but not IL-8 in the development of heat hyperalgesia: effects on heatevoked calcitonin gene-related peptide release from rat skin. J Neurosci Off J Soc Neurosci 20:6289-6293

Ormerod AD, Weller R, Copeland $P$ et al (1998) Detection of nitric oxide and nitric oxide synthases in psoriasis. Arch Dermatol Res 290:3-8

Ostadhadi S, Haj-Mirzaian A, Azimi E et al (2015) Involvement of nitric oxide in serotonin-induced scratching in mice. Clin Exp Dermatol 40:647-652. doi:10.1111/ced.12605

Patil MJ, Jeske NA, Akopian AN (2010) Transient receptor potential V1 regulates activation and modulation of transient receptor potential $\mathrm{A} 1$ by $\mathrm{Ca}^{2+}$. Neuroscience 171:1109-1119. doi:10.1016/ j.neuroscience.2010.09.031

Patricio ES, Costa R, Figueiredo CP et al (2015) Mechanisms underlying the scratching behavior induced by the activation of proteinase-activated receptor-4 in mice. J Invest Dermatol 135:2484-2491. doi:10.1038/jid.2015.183

Patwardhan AM, Jeske NA, Price TJ et al (2006) The cannabinoid WIN 55,212-2 inhibits transient receptor potential vanilloid 1 (TRPV1) and evokes peripheral antihyperalgesia via calcineurin. Proc Natl Acad Sci U S A 103:11393-11398. doi:10.1073/pnas.0603861103

Paulsen CE, Armache J-P, Gao Y et al (2015) Structure of the TRPA1 ion channel suggests regulatory mechanisms. Nature 520:511-517. doi:10.1038/nature14367

Pertovaara A, Koivisto A (2011) TRPA1 ion channel in the spinal dorsal horn as a therapeutic target in central pain hypersensitivity and cutaneous neurogenic inflammation. Eur $\mathrm{J}$ Pharmacol 666:1-4. doi:10.1016/j.ejphar.2011.05.027

Petrus M, Peier AM, Bandell M et al (2007) A role of TRPA1 in mechanical hyperalgesia is revealed by pharmacological inhibition. Mol Pain 3:40. doi:10.1186/1744-8069-3-40

Prescott ED, Julius D (2003) A modular PIP2 binding site as a determinant of capsaicin receptor sensitivity. Science 300:12841288. doi:10.1126/science. 1083646

Qian X, Francis M, Solodushko V et al (2013) Recruitment of dynamic endothelial $\mathrm{Ca}^{2+}$ signals by the TRPA1 channel activator AITC in rat cerebral arteries. Microcirc N Y N 1994 20:138-148. doi:10.1111/micc.12004

Rajasekhar P, Poole DP, Liedtke W et al (2015) P2Y1 receptor activation of the TRPV4 ion channel enhances purinergic signaling in satellite glial cells. J Biol Chem 290:29051-29062. doi:10.1074/jbc.M115.689729

Riol-Blanco L, Ordovas-Montanes J, Perro M et al (2014) Nociceptive sensory neurons drive interleukin-23-mediated psoriasiform skin inflammation. Nature 510:157-161. doi:10.1038/ nature13199

Romano B, Borrelli F, Fasolino I et al (2013) The cannabinoid TRPA1 agonist cannabichromene inhibits nitric oxide production in macrophages and ameliorates murine colitis. $\mathrm{Br} \mathrm{J}$ Pharmacol 169:213-229. doi:10.1111/bph.12120

Roosterman D, Goerge T, Schneider SW et al (2006) Neuronal control of skin function: the skin as a neuroimmunoendocrine organ. Physiol Rev 86:1309-1379. doi:10.1152/physrev.00026. 2005

Russell FA, Veldhoen VE, Tchitchkan D, McDougall JJ (2010) Proteinase-activated receptor-4 (PAR4) activation leads to sensitization of rat joint primary afferents via a bradykinin B2 receptor-dependent mechanism. J Neurophysiol 103:155-163. doi:10.1152/jn.00486.2009

Salas MM, Hargreaves KM, Akopian AN (2009) TRPA1-mediated responses in trigeminal sensory neurons: interaction between TRPA1 and TRPV1. Eur J Neurosci 29:1568-1578. doi:10.1111/j. 1460-9568.2009.06702.x

Salem SAM, Abdel Fattah NSA, Tantawy SMA et al (2013) Neodymium-yttrium aluminum garnet laser versus pulsed dye laser in erythemato-telangiectatic rosacea: comparison of clinical efficacy and effect on cutaneous substance $(P)$ expression. J Cosmet Dermatol 12:187-194. doi:10.1111/jocd.12048

Saunders Cl, Fassett RG, Geraghty DP (2009) Up-regulation of TRPV1 in mononuclear cells of end-stage kidney disease patients increases susceptibility to $\mathrm{N}$-arachidonoyl-dopamine (NADA)-induced cell death. Biochim Biophys Acta 1792:10191026. doi:10.1016/j.bbadis.2009.07.008

Senning EN, Collins MD, Stratiievska A et al (2014) Regulation of TRPV1 ion channel by phosphoinositide (4,5)-bisphosphate: the role of membrane asymmetry. J Biol Chem 289:10999-11006. doi:10.1074/jbc.M114.553180

Sereflican B, Goksugur N, Bugdayci G et al (2016) Serum Visfatin, Adiponectin, and Tumor Necrosis Factor Alpha (TNF- $\alpha$ ) Levels in Patients with Psoriasis and their Correlation with Disease Severity. Acta Dermatovenerol Croat ADC 24:13-19

Shim W-S, Tak M-H, Lee M-H et al (2007) TRPV1 mediates histamine-induced itching via the activation of phospholipase A2 and 12-lipoxygenase. J Neurosci Off J Soc Neurosci 27:23312337. doi:10.1523/JNEUROSCI.4643-06.2007

Silva CR, Oliveira SM, Rossato MF et al (2011) The involvement of TRPA1 channel activation in the inflammatory response evoked by topical application of cinnamaldehyde to mice. Life Sci 88:1077-1087. doi:10.1016/j.Ifs.2011.03.017

Smart D, Gunthorpe MJ, Jerman JC et al (2000) The endogenous lipid anandamide is a full agonist at the human vanilloid receptor (hVR1). Br J Pharmacol 129:227-230. doi:10.1038/sj.bjp. 0703050

Smolyannikova VA, Kubanova AA, Karamova AE et al (2015) Role of the skin expression of neuropeptides, neurotrophins and their receptors in the pathogenesis of dermatoses. Arkh Patol 77:3339

Sonkoly E, Muller A, Lauerma Al et al (2006) IL-31: a new link between T cells and pruritus in atopic skin inflammation. J Allergy Clin Immunol 117:411-417. doi:10.1016/j.jaci.2005.10.033

Southall MD, Li T, Gharibova LS et al (2003) Activation of epidermal vanilloid receptor- 1 induces release of proinflammatory mediators in human keratinocytes. J Pharmacol Exp Ther 304:217-222. doi:10.1124/jpet.102.040675

Spahn V, Stein C, Zöllner C (2014) Modulation of transient receptor vanilloid 1 activity by transient receptor potential ankyrin 1 . Mol Pharmacol 85:335-344. doi:10.1124/mol.113.088997

Ständer S, Moormann C, Schumacher M et al (2004) Expression of vanilloid receptor subtype 1 in cutaneous sensory nerve fibers, 
mast cells, and epithelial cells of appendage structures. Exp Dermatol 13:129-139. doi:10.1111/j.0906-6705.2004.0178.x

Staruschenko A, Jeske NA, Akopian AN (2010) Contribution of TRPV1-TRPA1 interaction to the single channel properties of the TRPA1 channel. J Biol Chem 285:15167-15177. doi:10.1074/jbc. M110.106153

Steinhoff M, Neisius U, Ikoma A et al (2003) Proteinase-activated receptor-2 mediates itch: a novel pathway for pruritus in human skin. J Neurosci Off J Soc Neurosci 23:6176-6180

Story GM, Peier AM, Reeve AJ et al (2003) ANKTM1, a TRP-like channel expressed in nociceptive neurons, is activated by cold temperatures. Cell 112:819-829

Sugiura T, Tominaga M, Katsuya H, Mizumura K (2002) Bradykinin lowers the threshold temperature for heat activation of vanilloid receptor 1. J Neurophysiol 88:544-548

Sura L, Zíma V, Marsakova L et al (2012) C-terminal Acidic cluster is involved in $\mathrm{Ca}^{2+}$-induced regulation of human transient receptor potential Ankyrin 1 channel. J Biol Chem 287:18067-18077. doi:10.1074/jbc.M112.341859

Szallasi A, Blumberg PM (1989) Resiniferatoxin, a phorbol-related diterpene, acts as an ultrapotent analog of capsaicin, the irritant constituent in red pepper. Neuroscience 30:515-520

Taylor-Clark TE, Undem BJ, Macglashan DW et al (2008) Prostaglandin-induced activation of nociceptive neurons via direct interaction with transient receptor potential A1 (TRPA1). Mol Pharmacol 73:274-281. doi:10.1124/mol.107.040832

Taylor-Clark TE, Ghatta S, Bettner W, Undem BJ (2009) Nitrooleic acid, an endogenous product of nitrative stress, activates nociceptive sensory nerves via the direct activation of TRPA1. Mol Pharmacol 75:820-829. doi:10.1124/mol.108.054445

Teresiak-Mikołajczak E, Czarnecka-Operacz M, Jenerowicz D, Silny W (2013) Neurogenic markers of the inflammatory process in atopic dermatitis: relation to the severity and pruritus. Post $\square$ py Dermatol Alergol 30:286-292. doi:10.5114/pdia.2013.38357

Thorne PS, Hawk C, Kaliszewski SD, Guiney PD (1991) The noninvasive mouse ear swelling assay. II. Testing the contact sensitizing potency of fragrances. Fundam Appl Toxicol Off J Soc Toxicol 17:807-820

Tominaga M, Caterina MJ, Malmberg AB et al (1998) The cloned capsaicin receptor integrates multiple pain-producing stimuli. Neuron 21:531-543

Tominaga M, Wada M, Masu M (2001) Potentiation of capsaicin receptor activity by metabotropic ATP receptors as a possible mechanism for ATP-evoked pain and hyperalgesia. Proc Natl Acad Sci U S A 98:6951-6956. doi:10.1073/pnas.111025298

Trevisani M, Siemens J, Materazzi S et al (2007) 4-Hydroxynonenal, an endogenous aldehyde, causes pain and neurogenic inflammation through activation of the irritant receptor TRPA1. Proc Natl Acad Sci U S A 104:13519-13524. doi:10.1073/pnas. 0705923104

Ufret-Vincenty CA, Klein RM, Collins MD et al (2015) Mechanism for phosphoinositide selectivity and activation of TRPV1 ion channels. J Gen Physiol 145:431-442. doi:10.1085/jgp.201511354

Vellani V, Mapplebeck S, Moriondo A et al (2001) Protein kinase C activation potentiates gating of the vanilloid receptor VR1 by capsaicin, protons, heat and anandamide. J Physiol 534:813825
Vellani V, Kinsey AM, Prandini M et al (2010) Protease activated receptors 1 and 4 sensitize TRPV1 in nociceptive neurones. Mol Pain 6:61. doi:10.1186/1744-8069-6-61

Vincent L, Vang D, Nguyen J et al (2013) Mast cell activation contributes to sickle cell pathobiology and pain in mice. Blood 122:1853-1862. doi:10.1182/blood-2013-04-498105

Wang S, Dai Y, Fukuoka T et al (2008a) Phospholipase C and protein kinase A mediate bradykinin sensitization of TRPA1: a molecular mechanism of inflammatory pain. Brain $\mathrm{J}$ Neurol 131:1241-1251. doi:10.1093/brain/awn060

Wang YY, Chang RB, Waters HN et al (2008b) The nociceptor ion channel TRPA1 is potentiated and inactivated by permeating calcium ions. J Biol Chem 283:32691-32703. doi:10.1074/jbc. M803568200

Wei H, Koivisto A, Pertovaara A (2010) Spinal TRPA1 ion channels contribute to cutaneous neurogenic inflammation in the rat. Neurosci Lett 479:253-256. doi:10.1016/j.neulet.2010.05.073

Wei T, Guo T-Z, Li W-W et al (2012) Keratinocyte expression of inflammatory mediators plays a crucial role in substance P-induced acute and chronic pain. J Neuroinflammation 9:181. doi:10.1186/1742-2094-9-181

Wilson SR, Bautista DM (2014) Role of transient receptor potential channels in acute and chronic itch. In: Carstens E, Akiyama T (eds) Itch: mechanisms and treatment. CRC Press, Boca Raton (FL)

Wilson SR, Gerhold KA, Bifolck-Fisher A et al (2011) TRPA1 is required for histamine-independent, Mas-related $\mathrm{G}$ protein-coupled receptor-mediated itch. Nat Neurosci 14:595-602. doi:10. 1038/nn.2789

Wilson SR, Nelson AM, Batia L et al (2013a) The ion channel TRPA1 is required for chronic itch. J Neurosci Off $J$ Soc Neurosci 33:9283-9294. doi:10.1523/JNEUROSCI.5318-12.2013

Wilson SR, Thé L, Batia LM et al (2013b) The epithelial cell-derived atopic dermatitis cytokine TSLP activates neurons to induce itch. Cell 155:285-295. doi:10.1016/j.cell.2013.08.057

Woo DH, Jung SJ, Zhu MH et al (2008) Direct activation of transient receptor potential vanilloid 1 (TRPV1) by diacylglycerol (DAG). Mol Pain 4:42. doi:10.1186/1744-8069-4-42

Xie Z (2009) [Role of thermo TRP channels in cutaneous neurogenic inflammation and itch]. Zhejiang Xue Xue Bao Yi Xue Ban J Zhejiang Univ Med Sci 38:409-414

Yang D, Luo Z, Ma S et al (2010) Activation of TRPV1 by dietary capsaicin improves endothelium-dependent vasorelaxation and prevents hypertension. Cell Metab 12:130-141. doi:10.1016/j. cmet.2010.05.015

Ye F, Deng P-Y, Li D et al (2007) Involvement of endothelial cellderived CGRP in heat stress-induced protection of endothelial function. Vascul Pharmacol 46:238-246. doi:10.1016/j.vph.2006. 10.008

Yusuf N, Nasti TH, Huang C-M et al (2009) Heat shock proteins HSP27 and HSP70 are present in the skin and are important mediators of allergic contact hypersensitivity. J Immunol Baltim Md 1950 182:675-683

Zhang N, Inan S, Cowan A et al (2005) A proinflammatory chemokine, CCL3, sensitizes the heat- and capsaicin-gated ion channel TRPV1. Proc Natl Acad Sci U S A 102:4536-4541. doi:10.1073/pnas.0406030102 
Zhang X, Li L, McNaughton PA (2008) Proinflammatory mediators modulate the heat-activated ion channel TRPV1 via the scaffolding protein AKAP79/150. Neuron 59:450-461. doi:10.1016/j. neuron.2008.05.015

Zhao P, Lieu T, Barlow N et al (2014) Cathepsin S causes inflammatory pain via biased agonism of PAR2 and TRPV4. J Biol Chem. doi:10.1074/jbc.M114.599712

Zhao Y, Bao L, Chan LS et al (2016) Aberrant wound healing in an epidermal interleukin-4 transgenic mouse model of atopic dermatitis. PLoS ONE. doi:10.1371/journal.pone.0146451

Ziegler SF, Roan F, Bell BD et al (2013) The biology of thymic stromal lymphopoietin (TSLP). Adv Pharmacol San Diego Calif 66:129-155. doi:10.1016/B978-0-12-404717-4.00004-4
Zupanc GK (1996) Peptidergic transmission: from morphological correlates to functional implications. Micron Oxf Engl 1993 (27):35-91

Zurborg S, Yurgionas B, Jira JA et al (2007) Direct activation of the ion channel TRPA1 by $\mathrm{Ca}^{2+}$. Nat Neurosci 10:277-279. doi:10. 1038/nn1843

Zygmunt PM, Petersson J, Andersson DA et al (1999) Vanilloid receptors on sensory nerves mediate the vasodilator action of anandamide. Nature 400:452-457. doi:10.1038/22761 